NBER WORKING PAPER SERIES

\title{
FORMAL EMPLOYMENT AND ORGANIZED CRIME: REGRESSION DISCONTINUITY EVIDENCE FROM COLOMBIA
}

\author{
Gaurav Khanna \\ Carlos Medina \\ Anant Nyshadham \\ Jorge A. Tamayo \\ Working Paper 26203 \\ http://www.nber.org/papers/w26203
NATIONAL BUREAU OF ECONOMIC RESEARCH
1050 Massachusetts Avenue
Cambridge, MA 02138
August 2019

We thank seminar participants at UCSD, Michigan (H2D2), Rosario (Bogota), SoCCAM, PacDev, Empirical Studies of Conflict, Barcelona GSE Summer Forum, Economics of Risky Behavior (Bologna), Colombian Central Bank (Bogota), Minnesota (MWIEDC), Hawaii, and the Inter American Development Bank (AL CAPONE) for feedback, and Achyuta Adhvaryu, Jorge Aguero, Prashant Bharadwaj, Chris Blattman, Michael Clemens, Gordon Dahl, Rafael Di Tella, Gordon Hanson, Mauricio Romero, Emilia Tjernstrom, Juan Vargas, Mauricio Villamizar and Jeff Weaver for insightful comments. The views expressed herein are those of the authors and do not necessarily reflect the views of the National Bureau of Economic Research, and do not commit Banco de la República or its Board of Directors.

NBER working papers are circulated for discussion and comment purposes. They have not been peer-reviewed or been subject to the review by the NBER Board of Directors that accompanies official NBER publications.

(C) 2019 by Gaurav Khanna, Carlos Medina, Anant Nyshadham, and Jorge A. Tamayo. All rights reserved. Short sections of text, not to exceed two paragraphs, may be quoted without explicit permission provided that full credit, including $\odot$ notice, is given to the source. 
Formal Employment and Organized Crime: Regression Discontinuity Evidence from Colombia Gaurav Khanna, Carlos Medina, Anant Nyshadham, and Jorge A. Tamayo

NBER Working Paper No. 26203

August 2019

JEL No. J24,J46,K42

\section{$\underline{\text { ABSTRACT }}$}

Canonical models of crime emphasize economic incentives. Yet, causal evidence of sorting into criminal occupations in response to individual-level variation in incentives is limited. We link administrative socioeconomic microdata with the universe of arrests in Medellín over a decade. We exploit exogenous variation in formal-sector employment around a socioeconomic-score cutoff, below which individuals receive benefits if not formally employed, to test whether a higher cost to formal-sector employment induces crime. Regression discontinuity estimates show this policy generated reductions in formal-sector employment and a corresponding spike in organized crime, but no effects on crimes of impulse or opportunity.

\author{
Gaurav Khanna \\ University of California, San Diego \\ 9500 Gilman Drive \\ La Jolla, CA 92037 \\ gauravk@ucsd.edu \\ Carlos Medina \\ Medellín Branch \\ Banco de la República \\ Calle 50 \# 50-21 \\ Piso 2 Medellín \\ Colombia \\ cmedindu@banrep.gov.co
}

\author{
Anant Nyshadham \\ Department of Economics \\ Boston College \\ Maloney Hall, 324 \\ Chestnut Hill, MA 02467 \\ and NBER \\ nyshadha@bc.edu \\ Jorge A. Tamayo \\ Harvard Business School \\ Soldiers Field, Morgan Hall 292 \\ Boston, MA 02163 \\ jtamayo@hbs.edu
}




\section{Introduction}

Many countries, particularly across the developing world and in much of Latin America, are plagued by coincident high degrees of informality in the labor market and criminal activity, often controlled by organized enterprises (Arteaga, 2019; Blattman et al., 2017; Buonanno and Vargas, 2018; Chimeli and Soares, 2017; Dell et al., 2018; DiTella et al., 2010; DiTella and Schargrodsky, 2013; Dix-Carneiro et al., 2018; Sviatschi, 2018). However, the empirical evidence on whether the two phenomena are causally linked by way of occupational sorting decisions of individuals is limited. Classic models of criminal behavior contend that individuals rationally weigh the expected costs and benefits of engaging in criminal activity (Becker, 1968; Ehrlich, 1973). Here, economic incentives play an important role via alternatives to crime: primarily legitimate employment in the labor market. Recent studies have confirmed that crime deterrence can be effective in reducing criminal activity (DiTella and Schargrodsky, 2013, 2014). However, understanding the economic decision to engage in crime is important, as reducing crime through incapacitation can be less effective when the elasticity of individual supply to crime is high (Freeman, 1999).

We use rich administrative data between 2002 and 2013 from Medellín, Colombia to test the relationship between formal employment and participation in crime at the individual level. In this empirical context, where informal employment is common and criminal enterprise activity abounds, financially dissuading individuals from engaging in formal employment could drive some to organized crime as their most lucrative option in the informal sector. Exploiting a discontinuity in the cost of formal work in Colombia, we leverage individual-level variation to empirically illustrate the occupational choice between formal employment and participation in criminal enterprise.

The Colombian government provides health benefits to all residents that reside within a household that has a socio-economic score (known as the Sisben score) below a certain threshold. Those formally employed are automatically taxed a fraction of their wages to avail of comparable benefits. Formal employment of any member affects the family's eligibility for this program, raising the relative benefits to other forms of employment. ${ }^{1}$ That is, the usual benefits to formal

\footnotetext{
${ }^{1}$ Eligibility is determined at the family level, with the employment status and incomes of children under the
} 
employment (e.g., higher wages, job security, legal protections) are at least partially offset by the increased cost of health care coverage for those below the cutoff who would be eligible for full coverage by the government if they were not formally employed. Near complete health care coverage in the population, despite costs representing large proportions of income for many households, reveals the importance of these incentives in this context.

Using a regression discontinuity design, we find that the policy induced a roughly 4 percentage point lower formal employment rate at the margin, consistent with estimates from previous studies. $^{2}$ These same individuals are more likely to be arrested for crimes associated with organized criminal activity. At the RD cutoff we find a 0.45 percentage point rise in gang-related violent crimes, a roughly 0.66 percentage point rise in gang-related property crimes, and a less precisely estimated 0.1 percentage point rise in gang-related drug crimes. ${ }^{3}$

Importantly, offenses less likely to be associated with economically motivated organizations, like rape and marijuana consumption, do not show significant increases at the cutoff, allowing us to rule out many alternative theories. ${ }^{4}$ At the margin, the program raised the cost of being employed in the formal sector. High-crime environments like Medellín have an informal market that contains many lucrative "employment" opportunities with organized criminal enterprises (i.e., gangs). In fact, related studies have argued that profit-making criminal activity is fully controlled by these organized entities such that most, if not all, economically motivated criminal activity occurs under their oversight (Blattman et al., 2018). Indeed, additional results show that impacts on gang-related criminal arrests are strongest in neighborhoods known to have the highest gang opportunities at baseline. Our results suggest that increases in formal employment can lead to reductions in criminal activities linked to these organized entities. Our magnitudes are similar to the related literature, as we measure an economically meaningful $3.1 \%$ increase

age of 25 living at home also determining eligibility. Accordingly, parents may have reason to discourage their children from joining the formal sector to avoid losing access to benefits. At the beginning of our sample period, the subsidized program covered nearly $60 \%$ of health services that the full program covered - this fraction increased consistently to eventually cover $100 \%$ of services.

${ }^{2}$ When evaluating the effect on the entire country using a different research design, Camacho et al. (2014) find that the program led to a 4 percentage point decrease in formal employment, consistent with the point estimate we obtain. Despite the reduction in formal employment, reported incomes are not significantly different at the cutoff suggesting a replacement with informal sources of economic activity.

${ }^{3}$ Additional results in which joint outcomes of non-formal employment and criminal arrests are studied confirm that those leaving formal work and those arrested are the same. The results for gang-related drug crimes are significant when we simultaneously measure both non-formal employment and arrests as an outcome.

${ }^{4}$ For instance, if social benefits induce risky behavior it should increase non-gang crimes as well. 
in arrests for every 1 percentage point fall in formal employment. ${ }^{5}$

Even though models of criminal activity are based on individual behavior, we often test these models using aggregate area-based relationships like unemployment shocks (Agan and Makowsky, 2018; Bennett and Ouazad, 2018; Cornwell and Trumbull, 1994; Entorf, 2000; Foley, 2011; Fougere et al., 2009; Gould et al., 2002; Karin, 2005; Lin, 2008; Machin and Meghir, 2004; Raphael and Winter-Ember, 2001). Area-based relationships are meaningful and policy relevant as they inform how to broadly target crime deterrence strategies. Yet, variation at the individual level is likely to produce different estimates than those that rely on aggregate shocks. ${ }^{6}$ In our work, we are interested in the individual-level decision to engage in criminal activity as it allows us to understand (and potentially address) some root causes of why youth choose a life of crime.

Some of the literature's best evidence of individual-level economic decisions related to crime comes from experiments that raise the human capital of individuals (Berk et al., 1980; Blattman and Annan, 2015; Bloom, 2006; Heller, 2014; Kemple et al., 1993; Schochet et al., 2008). We complement this evidence on how changes to human capital affect the returns to both standard employment and criminal activity, by examining the occupational choice between legitimate and illegitimate activity as relative incentives are changed. Many studies that attempt to examine individual-level occupational choices between legitimate and criminal activities rely on associations conditional on extremely rich sets of observables (Freeman, 1999; Grogger, 1998; Gronqvist, 2017; Lochner, 2004), as plausibly exogenous variation is challenging to find. ${ }^{7}$

\footnotetext{
${ }^{5}$ In their review of the recent literature, Bennett and Ouazad (2018) show that prior studies usually find that 1 percentage point increase in unemployment rates are associated with a $3-7 \%$ increase in crime. In Section 8 we discuss why our elasticities may be on the lower side of estimates in prior work.

${ }^{6}$ For example, unemployment at the regional level reduces the returns to criminal activity (i.e., lowers the resources available to expropriate and is correlated with fewer potential victims in the area (Mustard, 2010)). General equilibrium effects in which a new stock of criminals may crowd-out others, and neighborhood and peer effects both within and across neighborhoods might affect the relationship between area-based employment and choices to engage in crime (Cullen et al., 2006; Dustmann and Damm, 2014; Ihlanfeldt, 2007; Kling et al., 2005, 2007). Fella and Gallipoli (2014) find that general equilibrium effects explain a substantial portion of the relationship between crime and schooling. Additionally, detection rates of crime outcomes may defer as local resources change. Lastly, economic activity and high-income individuals may leave areas with high or increasing crime (Cullen et al., 2005; Cullen and Levitt, 1999; Greenbaum and Tita, 2004), further affecting the association between crime and employment observed at the aggregate level.

${ }^{7}$ It may be difficult to account for unobservables that would determine both employment and crime. For example, factors like high discount rates determine both crime and job-search (DellaVigna and Paserman, 2005; Golsteyn et al., 2014), whereas childhood shocks and decisions may affect both adult employment and crime (Doyle, 2008, 2007; Lochner and Moretti, 2004; Sviatschi, 2018). Reverse causality leads to upward bias as employers are less likely to prefer individuals that may display attributes correlated to criminal behavior
} 
Lastly, many studies depend on self-reported crime that may under-measure the occurrence of criminal activity, or homicides and victim-based data which capture the likelihood of being a victim rather than a criminal (Freeman, 1999).

We overcome each of these issues raised by previous researchers in examining the relationship between formal employment and criminal activity in Medellín, Colombia. First, we link two sources of administrative data at the individual level: the universe of arrests and the prearrest socio-economic characteristics of citizens, overcoming measurement issues in self-reported criminal activity and aggregate area-based measures of crime. Administrative individual-level data allow us to leverage individual-level variation and focus on demographics more likely to be affected. Next, we exploit quasi-experimental variation in the relative cost of formalsector employment (or relative benefits to informal employment) derived from a social benefits program that requires individuals to be outside the formal sector to be eligible. Rather than associations conditional on observables, we use exogenous variation in financial incentives to isolate the individual-level relationship between employment and crime. Last, our data allow us to distinguish between different types of crime and conduct falsification tests by comparing the impacts on crimes most likely associated with economically motivated criminal organizations to the impacts on other, more idiosyncratic crimes of impulse and opportunity.

Our contributions lie in validating economic models of occupational choice and criminal behavior (Becker, 1968; Ehrlich, 1973), leveraging individual-level variation in employment incentives and rich individual-level administrative data to establish a causal relationship between formal employment and crime. Such evidence has proven difficult to find in a literature that has mostly relied on aggregate shocks. Recent studies have highlighted how unemployment shocks, job loss and employment restrictions have lead to increases in criminal activity (Bennett and Ouazad, 2018; Pinotti, 2017; Rose, 2019). Our paper complements this small set of recent studies by testing occupational choice as a result of exogenous variation in exposure to a tax to formal wages. ${ }^{8}$ In addition, we stress the importance of distinguishing between different types (Grogger, 1995; Kling, 2006; Lott, 1992). Unemployment rates can affect the number of victims even if there are no new criminals: employed persons may have resources that are targeted, or the unemployed may be in the crossfire or suffer substance abuse.

${ }^{8}$ We think our estimated elasticities could differ substantially as job losses and structurally imposed employment restrictions may additionally induce effects on depression, subsequent job search, social stigma etc. 
of crime, as some are more likely to be associated with organized criminal enterprises (e.g., homicide) whereas others are more likely to be crimes of impulse, addiction or opportunity (e.g., rape and drug consumption). In doing so, we establish a falsification test to rule out alternative mechanisms that have little to do with occupational choice.

Finally, there are few studies in the developing world, as many look at the US, the UK or Scandinavian countries from which data are more readily available (Bhuller et al., 2018; Dustmann and Damm, 2014; Freeman, 1999). In contrast, we study a high-crime environment similar to most parts of the developing world and, in particular, a city with a significant presence of organized crime, which has been shown to have particularly detrimental effects on growth and development (Alesina et al., 2017; Melnikov et al., 2019), and broader consequences for child development (Arteaga, 2019). ${ }^{9}$ We build upon recent evidence from important high-crime environments in Latin America that leverages area-based variation from trade-shocks (Dell et al., 2018; Dix-Carneiro et al., 2018), or district-level unemployment (Buonanno and Vargas, 2018; Cortes et al., 2016). ${ }^{10}$ Finally, we highlight an unintended, adverse consequence of welfare policy, contributing to previous work on the interaction between public sector interventions and crime (Chimeli and Soares, 2017; Chioda et al., 2016; Doyle, 2008; Yang, 2008). ${ }^{11}$

\section{Background}

\subsection{Crime in Medellín}

Located in the north-western region of Colombia, Medellín is the second largest city after the capital, Bogota. It has strong industrial and financial sectors with approximately 2.3 million people or $5.5 \%$ of the Colombian population. The urban zone consists of 249 neighborhoods, divided into 21 (comunas), 5 of which are semi-rural townships (corregimientos).

\footnotetext{
${ }^{9}$ More than one in five young men in our sample were arrested. Our high crime context is similar to many parts of the developing world, including other parts of Latin America. In the developed world, the US has high incarceration rates (Kearney et al., 2014) but relatively lower crime rates.

${ }^{10}$ This literature also shows that local trade shocks also affect public goods provisioning, inequality and policing, suggesting that the general equilibrium effects may be substantial (Dix-Carneiro et al., 2018; Feler and Senses, 2017). Indeed, Dix-Carneiro et al. (2018) extensively discuss the various channels through which such aggregate shocks may affect crime.

${ }^{11}$ Related work studies how elected officials may engage in criminal activity (Ferraz and Finan, 2008, 2011; Olken and Pande, 2012), and how multiple prices for public programs lead to distortions (Barnwal, 2018).
} 
Although Colombian violence has traditionally been high, the emergence of drug cartels in the late 1970s and early 1980s, fueled the emergence of organized crime to support illegal businesses, and guerrilla or paramilitary groups to care for the entire production chain. From the mid 1980s to early 1990s, homicide rates rose rapidly driven by the boom of cartels, paramilitaries, and local gangs. Medellín used to be one of the most violent cities in the world (CCSPJP, 2009), placing our analysis among a handful that study motivations behind joining organized crime in high-crime environments. The high homicide rates are a result of fights among urban militias, local gangs, drug cartels, criminal bands, and paramilitaries based in surrounding areas. ${ }^{12}$ Many demobilized militias continue to be involved in crimes like extortion and trafficking, given their experience with using guns and avoiding police (Rozema, 2018).

There are two features of the homicide rate that are pertinent for our analysis. First, it is predominantly male. In 2002, the first year of our data, the male homicide rate was 184 per 100,000 whereas the female homicide rate was about 12, less than one-tenth the rate of males. Over the entire sample period (2005-13), 12\% of all males (across all age groups) were at some point arrested, while the arrest rate for females was only 1\%. Second, youth, between 13 and 26 years, are far more likely to be involved as victims or assailants than other age groups. Approximately, $63 \%$ of first arrests are between 13 and 26. Younger individuals are more likely to be engaged in drug trafficking and consumption, whereas slightly older individuals are involved in violent crimes (homicides, extortions, and kidnapping), and the oldest still are involved in property crime. Irrespective of type of crime, however, arrest rates peak within the 13 to 26 age window depicted in Figure A2.

In ongoing research, Blattman et al. (2018) document Medellín's criminal world as hundreds of well-defined street gangs (combos) which control local territories and are organized into hierarchical relationships of supply, and protection by the razones at the top of the hierarchy. They confirm that gangs are mainly profit-seeking organizations, earning money from protection, coercive services such as debt collection and drug sales. Anthropological studies and in person interviews show that economic incentives (such as the focus of our study) drive young men in Medellín to join organized crime (Baird, 2011). As many respondents highlight, the reason to

\footnotetext{
${ }^{12}$ Operacion Orion, followed by the demobilization of paramilitary forces led to a sharp decline in homicides, as the military clamped down on urban militias (Medina and Tamayo, 2011).
} 
join crime is mostly "economic" or for a profitable career. ${ }^{13}$ Knowing this, paramilitaries and gangs actively recruit idle youth that are amurrao (local slang, literally: 'sitting on the wall') and without a formal sector job.

An interview with El Mono ( $p 191)$ documents the recruitment process: "those guys would hang out around here and be nice to me and say 'come over here, have a bit of money'." Having a formal sector job means that one is not "hanging around the neighborhood" when the gangs come recruiting. A desirable outside option would be a job with benefits and social security, yet those with formal sector jobs pay extortion fees to gangs. ${ }^{14}$ Indeed, the options are often presented as an occupational choice: "are you gonna work [for the gang] or do a normal job?"15

Often, however, remunerations for gang-members are higher than jobs for those with similar levels of education (Doyle, 2016). New recruits are employed to run guns (carritos), before transitioning to extortion and trafficking. Blattman et al. (2018) estimate that foot soldiers of the combos receive well above national minimum wage whereas combo leaders earnings "put them in the top $10 \%$ of income earners in the city." These anecdotes are consistent with our hypothesis: higher costs of formal sector jobs (or better benefits for informal work) discourage youth from joining the formal sector, which in turn leads them to be recruited by gangs. ${ }^{16}$

For our sample of young men in the bandwidth of analysis, $21.5 \%$ were arrested over the period of study $-11.1 \%$ for drug crimes, $5.6 \%$ for property crime, and $4.8 \%$ for violent crimes. These numbers are high relative to most contexts, but are representative of cities in Latin America. The US has an incarceration rate more than six times the typical OECD nation, where one in ten youths from a low-income family may join a gang, $60 \%$ of crimes are committed by offenders under the age of 30 , and $72 \%$ by males (Kearney et al., 2014). Accordingly, in some regards, arrests in our context are similar to high-crime regions in many parts of the developing world, and especially Latin America (Dell et al., 2018).

\footnotetext{
${ }^{13}$ See interview with Gato, p264 and interview with Armando, p197.

${ }^{14}$ See interview with El Peludo, p184.

15 See interview with Notes, p193

${ }^{16}$ During the demobilization of militias in the mid-2000s, many were encouraged to join the formal sector, given identity cards and medical cards (Rozema, 2018). Yet, this disparity in costs across social benefit regimes, discourages formal sector re-integration.
} 


\subsection{Access to Health Benefits}

In 1993, Law 100 established two tiers of health insurance: the Contributive Regime (CR) and the Subsidized Regime (SR). The CR covers formal workers with a comprehensive set of health services that includes nearly all of the most common illnesses. The SR covers the families of the poorest informal workers and unemployed with a plan that initially covered fewer illnesses than CR, but was expanded to cover the same benefits. ${ }^{17}$ Formal workers and employers fund workers' insurance premiums for coverage by the CR. Between the 1993 reform and 1998, insurance coverage under both grew from $20 \%$ to $60 \%$. In 2005, SR was expanded and takeup reached 1.1 million people in Medellín, alone. By 2013, 96\% of Colombians were covered, with more than half qualifying under SR (Lamprea and Garcia, 2016).

Colombian employers are required by law to enroll all their employees in a Health Promoting Company, which gives them access to health insurance under the CR. Self-employed workers are allowed to enroll in the CR themselves by paying a monthly fixed amount based on a percentage of the monthly minimum wage. Unemployed or inactive individuals (and informal workers) can either get health insurance as the self-employed do through the CR, or apply for access to the SR. Individuals not covered by the CR or the SR use public hospitals, and are charged fees for both medicines and services.

Formal sector workers make up about $54 \%$ of the urban labor force and pay $4 \%$ of their monthly wage for enrollment in the CR, while the employer pays the other $8.5 \% .{ }^{18}$ This implies that effectively employees may bear a burden somewhere between 4 and $12.5 \%$ of their monthly wage depending on their bargaining power. Formal workers pay $1.5 \%$ of their salary to cover informal workers in SR. ${ }^{19}$ Over and above this, formal workers have to pay $4 \%$ of their wage for their pensions, and also bear other non-wage labor costs like old-age and disability insurance. These costs rose by between $10.5 \%$ and $11.5 \%$ after the 1993 reforms, with strong evidence that such costs discourage formal sector employment (Kugler and Kugler, 2009).

To target the SR, roughly 70 percent of the poorest households in the country were in-

\footnotetext{
${ }^{17}$ In 2008, the Constitutional Court ordered that the basket of health services covered under SR become equal to that of the CR. However, the reform did not come into effect until July 2012

${ }^{18}$ Employers' contribution was 8\% between 1993 (Law 100) and 2007. On that date it was increased to 8.5\% (Law 1122). This contribution was eliminated in 2012 (Law 1607) for incomes up to 10 times minimum wages.

${ }^{19}$ Authorities initially expected the formal sector population to rise and cover costs for SR. But the SR grew faster than the CR population, in part due to the lucrative nature of the SR (Lamprea and Garcia, 2016).
} 
terviewed between 1994 and 2003, and a welfare index (Sisben score) was calculated using a confidential formula based on respondent characteristics, incomes and assets, disability, education, and housing. Only households with a Sisben score below a certain cutoff and not formally employed were eligible to become beneficiaries of the SR. ${ }^{20}$ Other public programs use the Sisben score, but the SR Sisben cutoff did not coincide with other major interventions, at the eligibility cutoff of Sisben in the 2000s. ${ }^{21}$ The SR health program is by far the largest that has eligibility determined by the Sisben score. ${ }^{22}$

\subsection{Incentives for Informality}

Between 2005 and 2013, informal workers made up about $46 \%$ of the urban labor force in Medellin. Among informal workers, around $60 \%$ were own account workers, $20.5 \%$ were private sector employees, $7.8 \%$ were domestic workers, $7.7 \%$ self-employed workers, and the rest were laborers, family workers, and unpaid workers. Finally, 31.5\% of the workers had primary education, $51.8 \%$ secondary and $16.7 \%$ had some college education.

Effectively, financial incentives embodied in the health coverage options switch from potentially promoting formal employment above the cutoff due to a partial defrayal of the costs of healthcare by the employer, to strongly discouraging formal employment below the cutoff due to a significantly more enticing full defrayal of these large costs by the government for individuals who are not formally employed. Near complete health care coverage in the population despite costs representing large proportions of income, reveals the importance of these incentives. That this policy led to a fall in formal-sector employment has been documented in both the academic literature and public discourse. The Minister of Social Protection, in a news article in Presidencia de la Republica (February, 2006), claimed that the people's valuation of SR was so high that it discouraged formal employment. Studying the effects on the entire country, Camacho et al. (2014) use individual-level data and control for both region and time fixed effects to show that informal employment increased by 4 percentage points as SR was

\footnotetext{
${ }^{20}$ Households keep their Sisben score until it is updated by the government (expected to take place about every five years). In this case, the government updates the Sisben survey and score for the entire country.

${ }^{21}$ See www.sisben.gov.co/Paginas/Noticias/Puntos-de-corte.aspx for programs by Sisben 3 cutoff. While the Sisben cutoff for SR enrollment may differ across counties, there is only one cutoff for the entirety of Medellín,.

${ }^{22}$ The share of the SR in the total budget accounts to nearly $2 \%$ of the GDP, while all other programs sought to reduce poverty represent less than $0.4 \%$ of GDP.
} 
rolled out across the country. This is a combination of workers dropping out of the formal sector, but also fewer youth joining the formal sector over time (Lamprea and Garcia, 2016). Recognizing these adverse effects on formal employment, the government drastically lowered the costs of being enrolled in CR right at the end of our study period, when Law 1607 was enacted. This led to a significant increase in formal sector employment (Bernal et al., 2017; Fernández and Villar, 2017; Kugler et al., 2017; Morales and Medina, 2017).

Since the Sisben score and targeting is at the family level rather than individual level, older family members may discourage youth within the family from joining the formal labor force for fear of losing access to benefits. ${ }^{23}$ Large families stay informal in the hope of retaining benefits (Joumard and Londono, 2013). ${ }^{24}$ Indeed, Santamaria et al. (2008) find that half of all SR recipients indicated that they would not switch to formal employment as it would mean losing benefits. These effects are not restricted to men, as women's formal-sector participation also decreased in response to SR (Gaviria et al., 2007). Yet, we find that dis-employment effects on men are about four times larger than on women, consistent with the hypothesis that men have a lucrative alternative outside the formal sector: organized crime.

We leverage the fact that the costs of accessing these benefits change discontinuously at the Sisben cutoff. Indeed, as most individuals are covered by one healthcare regime or the other, ${ }^{25}$ almost everyone has similar access to benefits on either side of the cutoff. Yet, on one side of the cutoff these benefits are free only if you are not formally employed. The primary driving variation, therefore, is that being outside the formal sector allows you to not pay for benefits on one side of the cutoff. Since by the end of the period almost everyone has healthcare (under either one of the two regimes) and the benefits are similar across the two regimes, there are no discontinuous changes to health benefits at the cutoff.

\footnotetext{
${ }^{23}$ By Article 21, Decree 2353 of 205 , the Sisben score is determined at the family level.

${ }^{24}$ Similarly interviews in Baird (2011) highlight how being involved in crime can sometimes be a 'family decision' (chapter 6).

${ }^{25}$ By 2013 the coverage is $96 \%$ (Lamprea and Garcia, 2016).
} 


\section{Data}

Administrative data allow us to identify the relationship between the costs of formal employment and crime. We do not need to rely on self-reported or aggregate victim counts. As our data is at the individual-level we isolate vulnerable demographics (young men), and test both employment outcomes and crime. Additionally, detailed information on the types of crime allow us to isolate mechanisms.

We combine two sources of data at the individual level using national identification numbers and dates of birth. One source is from successive Sisben surveys of the Medellín population for three different years: 2002 (baseline Sisben I), 2005 (Sisben II) and 2009-2010 (Sisben III). The Sisben dataset consists of cross sections from censuses of the poor, and we match household records across the three waves. ${ }^{26}$ The second source is the census of individuals arrested between 2002-13 for each crime, whether or not they were convicted, from the Judicial Police Sectional of the National Police Department.

Our measure of criminal activity is arrests, rather than self-reported crime, and we acknowledge that either measure has its tradeoffs. We follow the literature and restrict our analysis to data on first arrests. Repeat arrests are excluded as time spent under incarceration and the length of sentencing may be endogenous to other characteristics. ${ }^{27}$ Indeed, first arrests most closely map to the first decision node between legal and illegal activities. Once captured a criminal career begins, with subsequent decisions to repeat, escalate, or exit the criminal sector based on many factors we do not observe (including prison sentences). Accordingly, subsequent criminal behavior is outside the scope of this study.

For similar reasons, we follow recent studies (Gronqvist, 2017; Kling et al., 2005) in focusing on young men in our analysis. Our primary sample is between 21 and 26 years old in the last year of our arrest data, or between 13 and 26 for the entire period (2005-2013) of study, capturing more than $63 \%$ of first arrests (as shown in Figure A2). Of the individuals arrested more than once during the observation period, $40 \%$ are first arrested before the age of 27 . At the same

\footnotetext{
${ }^{26}$ Municipalities survey a census of people living in the three poorest socioeconomic strata. In low income municipalities, the survey is a census of the whole population, while in larger cities it amounts to $65-80 \%$ of the population.

${ }^{27}$ Our results are robust to including repeat arrests.
} 
time, while incarcerated, individuals would not be able to be arrested for additional crimes and would, therefore, have lower measured propensities to be engaged in new criminal activity. Older individuals may have been arrested in their youth (or currently still be incarcerated) but as our crime data only begins in the early 2000s, we do not have their entire criminal history, and would miss their youth arrest. As such, we exclude older men. Focusing on ages when arrest rates peak reduces these concerns regarding the measurement of criminality, and allows us to emphasize the period when young men first make choices between crime and other jobs in Medellín (Doyle, 2016).

Figure A1 describes the timeline of our data. We use the 2002 Sisben as our baseline to create our running variable and predict eligibility for SR. ${ }^{28}$ We test for SR enrollment in the 2005 Sisben, and for employment status and incomes in the 2009 Sisben. We then follow the criminal histories of young men aged 21 to 26 in 2013, between 2005 (after we have a measure of SR enrollment from the second Sisben) and 2013. Even though we do not have a panel of formal sector work that follows the census of poor individuals in every year (along with their identification numbers), we do believe that this database, to the best of our knowledge, is one of the most comprehensive data exercises in such contexts.

In Appendix Table 1 presents the 2002 baseline summary statistics of the complete Sisben survey and for the subsample of males only. ${ }^{29}$ The arrests data include a detailed description of the person arrested (national identification number and date of birth), the type of crime (e.g., homicide, rape, motor vehicle theft, etc.), the precise article associated with the crime in the penal code, the date of arrest, the location of arrest, and a police generated flag for whether the arresting officer knew the perpetrator to be gang affiliated. We classify the crimes into three categories - violent, property, and drug crimes - based on the US Bureau of Justice Statistics' classifications in the Sourcebook of Criminal Justice Statistics (BJS, 1994). If an individual was first arrested for violent crime and later for property crime, they show up once as an arrest for violent crime.

\footnotetext{
${ }^{28}$ The formula to compute the Sisben score and the eligibility cutoff varies across the waves (I, II, and III).

${ }^{29}$ The SR status is established based on the previously computed Sisben score, based on the semi-decadal Sisben municipality census of the $70 \%$ of the poorest population. After a Sisben survey, it takes around one or two years to get the new Sisben score and whether the household becomes eligible. This is why the correct running variable to use is the lagged Sisben score.
} 
Table 1: Summary Statistics in 2002

\begin{tabular}{|c|c|c|c|c|}
\hline \multirow[b]{2}{*}{ Variable } & \multicolumn{2}{|c|}{ Complete Sample } & \multicolumn{2}{|c|}{ Males } \\
\hline & Mean & Std. Dev. & Mean & Std. Dev. \\
\hline \multicolumn{5}{|l|}{ Individual Characteristics } \\
\hline Male & 0.490 & 0.500 & 1.000 & 0.000 \\
\hline Subsidized Regime & 0.319 & 0.466 & 0.312 & 0.463 \\
\hline Contributive Regime & 0.228 & 0.420 & 0.222 & 0.416 \\
\hline Age 10-15 & 0.105 & 0.306 & 0.109 & 0.311 \\
\hline Age 15-20 & 0.105 & 0.306 & 0.110 & 0.313 \\
\hline Age $20-25$ & 0.089 & 0.285 & 0.093 & 0.290 \\
\hline Age $25-30$ & 0.068 & 0.251 & 0.068 & 0.251 \\
\hline Ever Arrested & 0.062 & 0.242 & 0.114 & 0.318 \\
\hline \multicolumn{5}{|l|}{ Household Head (HH) Characteristics } \\
\hline Female & 0.387 & 0.487 & 0.308 & 0.462 \\
\hline Employed & 0.628 & 0.483 & 0.643 & 0.479 \\
\hline Unemployed & 0.106 & 0.308 & 0.107 & 0.309 \\
\hline Married & 0.345 & 0.475 & 0.377 & 0.485 \\
\hline Attending School & 0.009 & 0.097 & 0.008 & 0.089 \\
\hline Has CR & 0.207 & 0.405 & 0.207 & 0.405 \\
\hline Age & 43.237 & 14.302 & 43.869 & 14.159 \\
\hline Years of Education & 4.542 & 2.451 & 4.480 & 2.454 \\
\hline Owns House & 0.314 & 0.464 & 0.327 & 0.469 \\
\hline Sisben Stratum 1 & 0.271 & 0.444 & 0.273 & 0.446 \\
\hline Sisben Stratrum 2 & 0.620 & 0.485 & 0.620 & 0.485 \\
\hline Sisben score & 45.707 & 9.901 & 45.716 & 9.908 \\
\hline Number of members in household & 4.090 & 1.709 & 4.215 & 1.709 \\
\hline $\mathrm{N}$ & \multicolumn{2}{|c|}{$1,161,446$} & \multicolumn{2}{|c|}{568,923} \\
\hline
\end{tabular}

Summary tabulations using Sisben I survey, conducted in the year 2002, and police arrests data.

Next, we divide crimes into crimes that would be more associated with an occupational choice. In Medellín, this implies being associated with a gang. The advantage of this additional classification is that we can test whether the decision to engage in crime is merely about income generation (e.g., engaging in petty theft property crime) or an occupational choice (gang crimes). While both are related, and consistent with the broader Becker (1968) hypothesis, we find that gang-crime arrests increase, even as non-gang income generating property crimes do not (and neither do non gang violent crimes of impulse or passion).

We worked closely with senior police officials in Medellín to divide our crimes into gangrelated and non gang-related crimes. Police officials inform us that the best way to classify 
arrests as gang related are along two dimensions: (1) the crime, and (2) the location. Fortunately, for about $30 \%$ of our data, the police used a system that flagged the arrest with whether the individual was known gang affiliate or not, and information on which gang the individual belonged to. This gang affiliation was based on police intelligence. As the gang-flag system was not available for the entirety of the period, we classify a crime as 'gang-related' if more than $30 \%$ of recorded arrests had the gang flag. ${ }^{30}$ As a result, for example, we classify homicides as violent gang-related, and rape or domestic violence as violent non gang-related. ${ }^{31}$

In robustness checks, we use a method that relies on the association between these crimes and historically high-gang neighborhoods. In this alternative definition, we classify those crimes as gang-related if they are disproportionately more likely (above the median) to list any of these high-gang neighborhoods as a location of arrest. While these two methods are not perfect, the robustness to alternative definitions gives us solace, and to the best of our knowledge, such a data exercise has not been conducted in such a comprehensive manner before. ${ }^{32}$

In Appendix Table A1, we categorize the 25 (of 103) most prevalent crimes under each classification method. These data-driven methods line up with our priors on types of crime: homicides, motor vehicle theft, extortion, kidnapping, break-ins, and the manufacturing, delivery and trafficking of drugs fall under organized crimes. The remaining crimes are often thought of as crimes of impulse or opportunity (like rape, simple assault, and drug consumption). Indeed, we can distinguish between minute details - such as trafficking cocaine (gang) vs consuming drugs (non gang). The advantage of these classification approaches is that they are purely data driven. Additionally, they may speak to the types of activities that gangs in Medellín engage in: for example, they are more likely to engage in car theft than identity theft.

\footnotetext{
${ }^{30}$ Our results are robust to using the median as the cutoff.

${ }^{31}$ Gang-rape gets classified as a gang crime. Our police contacts also describe how burglars are imbibed into gangs based on their work territories and would find it difficult to be a burglar without being a part of the gang.

${ }^{32}$ Additionally, using the crime-level classification (rather than the individual flags) of gang-related crimes protects us against any police biases against specific individuals, or their characteristics (such as insurance status or who the police have more intelligence on).
} 


\section{Enrollment in the Subsidized Regime (SR)}

As only households in the two lowest levels of Sisben I (2002), a score below 47, could qualify for the SR, we compare households on either side of the cutoff to identify the effect of SR eligibility. First, we verify if there is a discontinuity in the probability of SR enrollment at the cutoff. Second, we examine how the likelihood of being in the formal sector changes at the cutoff. Last, we examine the effect on different types of criminal activity.

In following RD conventions, we normalize the Sisben score so that treated units are individuals with positive values of our new score. Figure 1 presents the first stage: the discontinuity in the probability of SR enrollment using the optimal binning procedure found in Calonico et al. (2014a). The probability of enrollment discontinuously increases by around 26 percentage points. ${ }^{33}$ Not all eligible persons enroll in SR, as formal sector jobs may be valuable to some, but enrollment still jumps substantially to $42 \%$ at the cutoff.

Figure 1: Discontinuity in the Probability of SR enrollment at Cutoff.

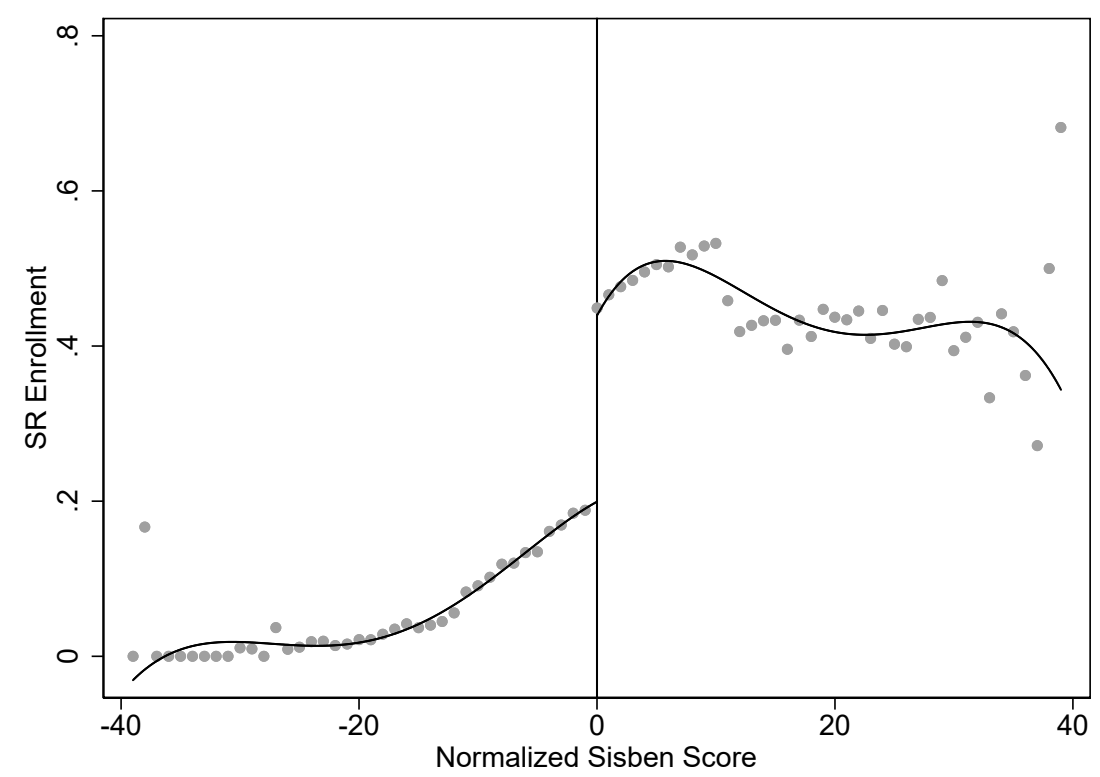

SR enrollment is probability of being enrolled in the subsidized regime in 2005. RD Graph using optimal binning procedure discussed in Calonico et al. (2014a). Normalized Sisben (2002) score on horizontal axis centered around cutoff. Higher values represent low scores (higher poverty).

For two-staged least squares (2SLS) exercises we follow a fuzzy regression discontinuity design, where our running variable is the 2002 Sisben score. We use both parametric and non-

\footnotetext{
${ }^{33}$ Around $20 \%$ of households that have a high 2002 Sisben also avail of SR in 2005, as a fraction of households became eligible under a smaller 1998 Sisben survey, and the government allows them to keep their benefits for some time after they graduate out of eligibility.
} 
parametric approaches to estimate the effect of SR eligibility at the cutoff. For the parametric approach we follow Hahn et al. (2001), where we instrument enrollment in the SR with the eligibility indicator $1\left[s_{i}<47\right]$, and estimate the following equation as our first stage:

$$
S R_{i, n}=\alpha+\alpha_{1} 1\left[s_{i, n}<47\right]+X_{i, n}^{\prime} \alpha_{2}+A_{i}\left(s_{i, n}\right) \alpha_{3}+\mu_{n}+\varepsilon_{i, n}
$$

where $A_{i}$ is a vector of smooth polynomial functions of the Sisben score of each individual, $s_{i, n}$. In robustness checks, we also estimate models conditioning on demographics and other baseline characteristics. Here $X_{i, n}$ is a vector of demographic characteristics for individual $i$ living in neighborhood $n$. $\mu_{n}$ corresponds to neighborhood fixed effects for the 249 neighborhoods. ${ }^{34}$

An important issue in practice is the selection of the smoothing parameter. We use local regressions to estimate the discontinuity in outcomes at the cutoff point. In particular, we estimate local polynomial regressions conducted with a rectangular kernel and employing the optimal data-driven procedure suggested by Calonico et al. (2014b). We use two different optimal bandwidth procedures: the Imbens and Kalyanaraman (2012) method and the Calonico et al. (2014b) bandwidth. The optimal bandwidths from the different procedures lie between 5.5 and 6.2 points, on the 100-point Sisben I scale. We present our results for multiple bandwidths to highlight the robust nature of our estimates, varying them from below the optimal bandwidths to larger bandwidths. Specifically, we check for coefficient stability for results spanning these bandwidths ranging between 4 and 10 points around the cutoff. Varying the size of the bandwidth and the polynomial order do not affect the results.

Our first stage results are shown in Table 2, displaying the 26 percentage point increase in SR enrollment shown in Figure 1. As we vary the bandwidths from 4 through 10 the coefficient is stable and both economically and statistically significant. The table also shows that the standard IV F-test suggests a strong instrument, and for our remaining outcomes we conduct two-staged least squares analyses using this is as our first stage.

\footnotetext{
${ }^{34}$ We include controls in robustness checks, where we control for various characteristics of the household head in 2002, the baseline year. These controls include an indicator for female-headed households, employment status, years of education, marital status, attendance to any academic institute, year-of-birth fixed effects, socioeconomic strata of the household, and home ownership.
} 
Table 2: SR Enrollment at Sisben Cutoff (First Stage)

\begin{tabular}{|c|c|c|c|c|}
\hline Variables & Bandwidths: & 4 & 6 & 10 \\
\hline \multicolumn{5}{|c|}{ Dependent Variable: Enrolled in SR (First Stage) } \\
\hline \multicolumn{2}{|l|}{ Below Sisben Cutoff } & $\begin{array}{c}0.260^{* * *} \\
(0.0138)\end{array}$ & $\begin{array}{c}0.260^{* * *} \\
(0.0132)\end{array}$ & $\begin{array}{c}0.269^{* * *} \\
(0.0110)\end{array}$ \\
\hline \multirow{3}{*}{\multicolumn{2}{|c|}{$\begin{array}{l}\text { F-stat of IV } \\
\text { Number of observations } \\
\text { Sample mean (in bandwidth) }\end{array}$}} & 354.97 & 387.97 & 598.02 \\
\hline & & 181,132 & 246,974 & 340,581 \\
\hline & & & & 0.36 \\
\hline
\end{tabular}

Note: Standard errors in parentheses. ${ }^{* * *}$ significant at $1 \%{ }^{* *}$ significant at $5 \%$; ${ }^{*}$ significant at $10 \%$. Coefficient of indicator of being below Sisben cutoff, with linear controls for 2002 Sisben scores that vary flexibly at the cutoff. SR enrollment as measured in the 2005 Sisben survey. Standard errors clustered at the comuna level.

\section{Impacts on Formal Employment and Reported Income}

We test the simple hypothesis that the SR conditions disincentivized formal-sector employment and led to an increase in organized-crime activities. We first reproduce a well-established result and show that the program has a negative effect on formal employment (Camacho et al., 2014; Gaviria et al., 2007; Joumard and Londono, 2013; Santamaria et al., 2008). We exploit the discontinuity in enrollment rates at the cutoff, by using the eligibility indicator as an instrument for enrollment status to identify the effect of SR on formal employment and income. Here $E m p_{i, n}$ is 1 if the individual $i$ from neighborhood $n$ was formally employed. In robustness checks we include demographic controls in $X_{i, n}$, and neighborhood fixed effects $\mu_{n}$. We show the reduced form relationship between employment and being above the RD cutoff:

$$
E m p_{i, n}=\gamma_{0}+\gamma_{1} 1\left[s_{i, n}<47\right]+X_{i, n}^{\prime} \gamma_{2}+A_{i}\left(s_{i, n}\right) \gamma_{3}+\mu_{n}+\varepsilon_{i, n}
$$

We then instrument for SR enrollment, where $S \hat{R}_{i, n}$ is the predicted SR enrollment probability from the first stage estimated in Equation 1. The second stage is:

$$
E m p_{i, n}=\beta_{0}+\beta_{1} S \hat{R}_{i, n}+X_{i, n}^{\prime} \beta_{2}+A_{i}\left(s_{i, n}\right) \beta_{3}+\mu_{n}+\epsilon_{i, n}
$$

Figure 2 captures the fall in formal sector employment at the cutoff, where formal employment is defined as a working individual making wage contributions to benefits as measured in 
Figure 2: Discontinuity in Formal Employment (2009).

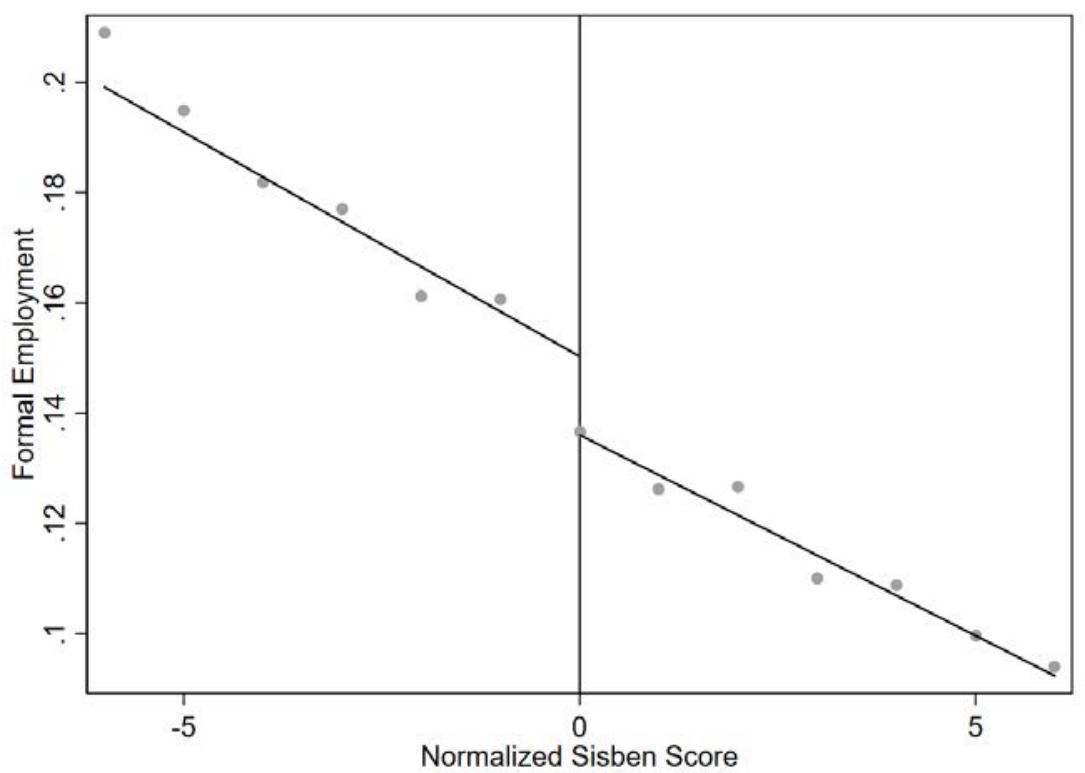

RD Graph using optimal binning procedure discussed in Calonico et al. (2014a). Formal employment based on measures in 2009 Sisben survey. Subsample of males. Normalized Sisben (2002) score on horizontal axis centered around cutoff. Higher values represent low scores (higher poverty).

the 2009 Sisben III survey. ${ }^{35}$ In our RD figures, we focus on a bandwidth of 6 around the cutoff as it is the Calonico et al. (2014b) optimal bandwidth.

Table 3 presents the results for reported formal employment and incomes in the 2009 Sisben survey. The table presents results for the reduced form change at the cutoff, and the two-staged least squares (2SLS) effect of enrolling in SR. These results show that the health insurance program had a negative impact of 4.1 percentage points (when using the optimal bandwidth) on the probability of being employed in the formal sector in 2009.

Lower formal sector employment at the cutoff may be a combination of fewer youth joining the formal sector as they enter working-age, lower transition rates out of informal work, and higher transition probabilities out of formal work at the cutoff. As formal sector employment affects SR enrollment for the entire family, these are often family decisions, where older family members may discourage youth from joining the formal sector (Joumard and Londono, 2013). This effect is larger for men than it is for women (Appendix Table A2), perhaps once again

\footnotetext{
${ }^{35}$ While this is a somewhat conservative measure of formal employment, Colombian employees who pay contributions to health insurance have been widely considered by the literature to be formal employees (See Attanasio et al., 2017; Morales and Medina, 2017). The Sisben does not explicitly ask households whether the worker is in the formal sector, which in any case, the response would be misreported underestimating the formality rate.
} 
Table 3: Reported Formal Employment and Income

\begin{tabular}{|c|c|c|c|c|}
\hline & Bandwidths: & 4 & 6 & 10 \\
\hline \multicolumn{5}{|c|}{ Panel A: Formal Employment in 2009 (Males) } \\
\hline $\begin{array}{l}\text { Above Cutoff } \\
\text { Reduced Form }\end{array}$ & & $\begin{array}{c}-0.0147^{* * *} \\
(0.00467)\end{array}$ & $\begin{array}{c}-0.0111^{* * *} \\
(0.00280)\end{array}$ & $\begin{array}{c}-0.00845^{* * *} \\
(0.00217)\end{array}$ \\
\hline $\begin{array}{l}\text { Enrolled in SR } \\
\text { 2SLS }\end{array}$ & & $\begin{array}{c}-0.0539 * * * \\
(0.0166)\end{array}$ & $\begin{array}{c}-0.0411^{* * *} \\
(0.0103)\end{array}$ & $\begin{array}{c}-0.0301^{* * *} \\
(0.00811)\end{array}$ \\
\hline $\begin{array}{l}\text { Number of observations } \\
\text { Sample mean (only male }\end{array}$ & andwidth for & $\begin{array}{l}133,067 \\
009)\end{array}$ & 180,742 & $\begin{array}{c}247,886 \\
0.14\end{array}$ \\
\hline
\end{tabular}

Panel B: Annual Household Income in 2009 (USD)

$\begin{array}{lccc}\text { Above Cutoff } & -3.837 & -3.805 & 2.347 \\ \text { Reduced Form } & (3.100) & (2.295) & (4.008) \\ & & & \\ \text { Enrolled in SR } & -6.481 & -3.042 & 30.49 \\ \text { 2SLS } & (9.163) & (8.842) & (27.83) \\ & & & \\ \text { Number of observations } & 46,797 & 63,457 & 87,510 \\ \text { Sample mean (households in bandwidth for 2009) } & & 171.24\end{array}$

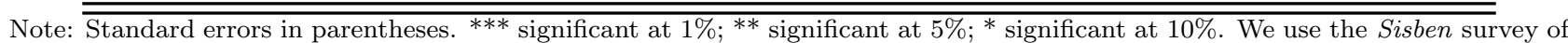
2009 to construct both outcome variables. Formal employment for males only. The results for women are presented in Table A2. Tables report Two-Staged Least Squares (2SLS) coefficients where the first stage is SR enrollment on being below the Sisben cutoff. Regressions control linearly for the Sisben score, flexibly around the cutoff. We cluster standard errors by comuna. Household-level income reported in pesos and converted to USD using the average 2009 exchange rate. Sample means for males and households only in bandwidth for 2009 .

highlighting that males have an outside option in organized crime. ${ }^{36}$

The impact on household-level income is statistically indistinguishable from zero and economically small (\$30 per household annually). One caveat is that income is self-reported, and respondents may under-report assets and incomes in order to get a lower Sisben score. However, as respondents do not know the score formula, perfect manipulation is impossible (whether or not they are part of a gang), and therefore, as we show below, the density of respondents is smooth around the cutoff.

We may especially expect that incomes from illicit activities are under-reported rather than

\footnotetext{
${ }^{36}$ Note, that we should not necessarily think of this result as a 'first-stage' on crime outcomes. Instead, crime and formal employment choices are jointly determined. Indeed, it is possible that, as we predict, the incentives lead individuals to leave the formal sector and join crime. After a few years in crime, an individual may wish to re-join the formal sector, but may be unable to do so given a criminal record.
} 
over-reported, perhaps suggesting that poverty-based desperation is less likely to be driving criminal activity. We should be wary of reading too much into these self-reported income measures, but if anything they suggest that even as workers drop out of the formal sector they find other sources of income. Indeed, by revealed preference, they choose to drop out of the formal sector, and as such, should be better off. Yet, we wish to be extremely careful in stressing the crudeness of self-reported income measures.

Canonical crime models (Becker, 1968; Ehrlich, 1973) stress the role of both income and substitution effects when wages in one sector change. In analyses that focus on legitimate sector job-loss and unemployment shocks, the income and substitution effects may work to both increase criminal activity. Interestingly, in contrast, here any gains from the subsidy essentially lower the likelihood of criminal activity.

Together, the results of this section show that higher costs of formal employment discouraged youth from joining the formal sector. As health care coverage via either regime is almost universal, individuals on either side have similar benefits, but on one side are more likely to choose to be outside of the formal sector to avoid high costs of maintaining this coverage. The obvious question that this then raises is how this aversion to formal sector employment affects the likelihood of criminal activity.

\section{Impacts on Crime}

We next turn our attention to outcomes on crime. One important distinction with the formal employment results is that we only measure formal employment in one year, whereas we measure crime cumulatively pooled over a decade. We interpret the impacts on crime as causally related to the incentives to leave the formal sector. ${ }^{37}$ We show both the reduced form and two-staged least squares estimates of impacts on crime. In the second stage, we use the eligibility indicator as an instrument for enrollment status to identify the effect of SR enrollment on crime. Here crime $_{i}$ is 1 if the individual $i$ was arrested between 2005 and $2013 .^{38}$

\footnotetext{
${ }^{37}$ Note that by the latter half of this period almost everyone had healthcare (under either one of the two regimes), and the benefits were similar. As such health benefits are not changing at the cutoff, only the incentives behind who pays for it changes.

${ }^{38}$ Even as we have crime data for many years, we have formal employment only recorded at one point of time in 2009. This poses challenges when trying to simultaneously measure changes in employment and crime. Yet
} 


$$
\operatorname{Crime}_{i, n}=\beta_{0}+\beta_{1} S \hat{R}_{i, n}+X_{i, n}^{\prime} \beta_{2}+A_{i}\left(s_{i, n}\right) \beta_{3}+\mu_{n}+\varepsilon_{i, n},
$$

Our main results do not condition on other factors. In robustness checks, we control for various characteristics of the household head in 2002, the baseline year. These controls include an indicator for female-headed households, employment status, years of education, marital status, attendance to any academic institute, year-of-birth fixed effects, socioeconomic strata of the household, ${ }^{39}$ home ownership, and neighborhood fixed effects. A literature on neighborhood effects and crime (Cullen et al., 2006; Dustmann and Damm, 2014) highlight the perils of using area-based relationships (like differences in unemployment rates) to study individual-level occupational choice, and re-iterates the strength of our approach. ${ }^{40}$ Our results are unaffected by the inclusion of neighborhood fixed effects that absorb any neighborhood level characteristics (demographics, amenities, property values and police presence) that may affect crime rates. We cluster standard errors at the comuna level.

We present results for violent, property, and drug-related crimes, dividing each group between organized-crime related activities and crimes less likely to be associated with organized criminal entities. We choose the most conservative specification, where when looking at the impacts on violent crime, we exclude those whose first arrests were in property or drug crime, and do the same for each type of crime. ${ }^{41}$ This is why our number of observations will differ by type of crime. As such, our outcome will be 1 if the person's first arrest was in violent crime, and 0 if they were never arrested in their youth. In robustness checks, we include the other types of crimes as 0s, and our results are more precisely estimated (see Appendix Table A8).

As discussed in the data section, at the point of arrest, the police record a flag if they suspect the arrested individual is involved with a gang or not. We calculate the propensity for being issued this flag for each type of crime, and divide crimes into two groups: high and low-propensity to be organized criminal activity. This data-driven method to group crimes our results are robust to doing so (Appendix Table A9).

${ }^{39}$ Urban areas in Colombia are split into six socioeconomic strata, used by authorities to spatially target social spending to neighborhoods.

${ }^{40}$ There may still be general equilibrium effects of the policy that affect the entire country, but since our variation is not driven by differences across neighborhoods, this is all netted out.

${ }^{41}$ Not doing so increases the precision of our estimates (Appendix Table A8). 
produces intuitive classifications (Table A1).

We hypothesize that organized criminal activities are directly related to our implicit model of occupational choice across legitimate and illegitimate sectors, whereas non-gang-related crimes should be less affected by the opportunity cost of being in the formal sector and hence serve as a useful falsification test. We expect the effects on the latter group to be zero, as crimes of impulse and passion are less directly related to occupational choice.

As we elaborate in a later discussion, over and above a falsification test, the lack of effects on non-gang crimes also allow us to rule out alternative mechanisms. We do not classify crimes based on whether or not they are pecuniary as that captures crimes of desperation and necessity that arise out of poverty. Instead, we posit that the policy induced an occupational choice to work for a gang, and as such use organized crime as a basis for classification. Alternative mechanisms (such as riskier behavior when having insurance) may have weight if non-gang crimes rose as well, but the lack of effects on non-gang crimes allow us to rule them out.

\subsection{Violent Crime}

We first start with the probability of being arrested for violent criminal activities. Based on the police flags for gang-related activity, violent organized crimes include homicides, extortion, and kidnapping. Violent crimes less likely to be associated with an organized entity include domestic violence, rape and injuries. Figure 3 and Table 4 present the results.

Figure 3 shows the jump in violent gang-related crime arrests at the Sisben cutoff, concentrating on an optimal bandwidth of 6 points on the 100 point scale. In Table 4 we present the regression discontinuity results varying the bandwidth and specifications. The reduced form results (first row in each panel) show an increase in gang-related violent crime (Panel A), but no corresponding change in less gang-related violent crime (Panel B). Within a bandwidth of 10 points on the Sisben scale, and measuring arrests over a decade, these results amount to a $32 \%$ increase (or a 0.45 percentage point increase) in violent crime arrests from the mean around the cutoff. These magnitudes are both economically meaningful and similar to those from recent studies in other contexts (Pinotti, 2017).

Our 2SLS results (next two rows of each panel) show an economically and statistically 
Table 4: Violent Crimes

\begin{tabular}{|c|c|c|c|c|}
\hline & Bandwidths: & 4 & 6 & 10 \\
\hline \multicolumn{5}{|c|}{ Panel A: More Gang-Related Violent Crimes } \\
\hline $\begin{array}{l}\text { Above Cutoff } \\
\text { Reduced Form }\end{array}$ & & $\begin{array}{c}0.00722^{* * *} \\
(0.00236)\end{array}$ & $\begin{array}{c}0.00649^{* *} \\
(0.00249)\end{array}$ & $\begin{array}{r}0.00456^{* *} \\
(0.00164)\end{array}$ \\
\hline $\begin{array}{l}\text { Enrolled in SR } \\
\text { No Covariates }\end{array}$ & & $\begin{array}{c}0.0257^{* * *} \\
(0.00873)\end{array}$ & $\begin{array}{c}0.0231^{* * *} \\
(0.00838)\end{array}$ & $\begin{array}{r}0.0158^{* * *} \\
(0.00539)\end{array}$ \\
\hline $\begin{array}{l}\text { Enrolled in SR } \\
\text { Including pre-treatment covariates }\end{array}$ & & $\begin{array}{c}0.0274^{* * *} \\
(0.00950)\end{array}$ & $\begin{array}{l}0.0232^{* *} \\
(0.00937)\end{array}$ & $\begin{array}{l}0.0149^{* *} \\
(0.00583)\end{array}$ \\
\hline $\begin{array}{l}\text { Number of observations } \\
\text { Sample mean (men } 13-26 \text { years old } \\
\text { Sample mean for those enrolled in }\end{array}$ & $\begin{array}{l}\text { andwidth) } \\
\text { and in high-gan }\end{array}$ & 18,052 & 24,272 & $\begin{array}{c}33,027 \\
0.014 \\
0.020\end{array}$ \\
\hline
\end{tabular}

Panel B: Less Gang-Related Violent Crimes

\begin{tabular}{lccc} 
Above Cutoff & 0.00279 & 0.000988 & -0.000581 \\
Reduced Form & $(0.00454)$ & $(0.00304)$ & $(0.00326)$ \\
& & & \\
Enrolled in SR & 0.00994 & 0.00349 & -0.00201 \\
No Covariates & $(0.0158)$ & $(0.0104)$ & $(0.0110)$ \\
& & & \\
Enrolled in SR & 0.00791 & 0.00118 & -0.00322 \\
Including pre-treatment covariates & $(0.0168)$ & $(0.0111)$ & $(0.0125)$ \\
& & & \\
Number of observations & 18,419 & 24,768 & 33,702 \\
Sample mean (men 13-26 years old in bandwidth) & & & 0.034 \\
Sample mean for those enrolled in SR and in high-gang comuna & & 0.039 \\
\hline
\end{tabular}

Note: Standard errors in parentheses. ${ }^{* * *}$ significant at $1 \%{ }^{* *}$ significant at $5 \%{ }^{*}$ significant at $10 \%$. Tables report reduced form and two-staged least squares (2SLS) coefficients where the first stage is SR enrollment on being below the Sisben cutoff. The Sisben score is measured in 2002, and SR enrollment in 2005. We measure crime between 2005 and 2013. Regressions control linearly for the Sisben score, flexibly around the cutoff. We cluster standard errors by comuna. We consider only males between 21 to 26 years old in 2013. For regressions that have pre-treatment covariates, we include household characteristics, year of birth fixed effects, and neighborhood fixed effects. The sample excludes anybody whose first arrest was a property or drug crime (Appendix Table A8 includes these observations as a robustness). 


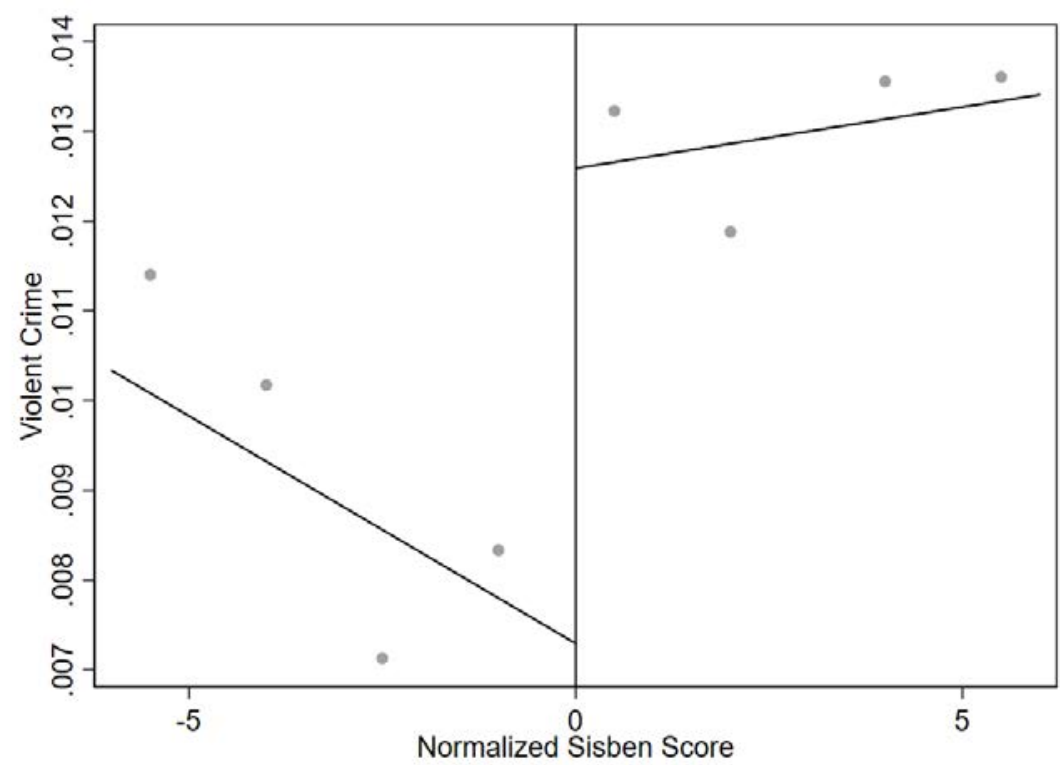

RD Graph using optimal binning procedure discussed in Calonico et al. (2014a). Normalized Sisben (2002) score on horizontal axis centered around cutoff. Higher values represent low scores (higher poverty).

significant increase in the probability of gang-related violent arrests for individuals enrolled in SR. We do not find any meaningful effect on the arrest probability for non organized-crime related violence. A comparison of the various rows in each panel shows that the estimates are robust to including controls, whereas a comparison across columns shows the robustness to bandwidths. While we do not report t-tests for the difference between gang and less-gang related crimes, the coefficients are statistically significantly different for all bandwidths.

\subsection{Property Crime}

In Figure 4 and Table 5 we analyze the effects on property crimes. Based on police flags, we establish that gang-related property crimes include crimes like motor vehicle theft and break-ins to businesses and residences. Crimes like fraud and identify theft are classified as less gangrelated. Once again, in the reduced form we see that gang-related property crimes increase, with little change to less gang-related property crimes. This estimate, over the entire decade, constitutes a $21 \%$ increase (or a 0.66 percentage point increase) from the mean around the cutoff within a bandwidth of 10 points.

In the 2SLS results, we also find an economically and statistically significant increase for gang related property crime arrests, and no strong effect for property crimes less associated 
Table 5: Property Crimes

\begin{tabular}{lccc}
\hline \hline \multicolumn{1}{c}{ Bandwidths: } & 4 & 6 & 10 \\
\hline \multicolumn{4}{c}{ Panel A: More Gang-Related Property Crimes } \\
& & & \\
& $0.0106^{* *}$ & $0.00930^{* *}$ & $0.00666^{*}$ \\
Above Cutoff & $(0.00387)$ & $(0.00389)$ & $(0.00350)$ \\
Reduced Form & & & \\
& $0.0380^{* * *}$ & $0.0331^{* * *}$ & $0.0232^{* *}$ \\
Enrolled in SR & $(0.0123)$ & $(0.0126)$ & $(0.0113)$ \\
No Covariates & & & \\
& $0.0408^{* * *}$ & $0.0341^{* * *}$ & $0.0240^{* *}$ \\
Enrolled in SR & $(0.0139)$ & $(0.0131)$ & $(0.0108)$ \\
Including pre-treatment covariates & & & \\
& 18,426 & 24,740 & 33,625 \\
Number of observations & & & 0.032 \\
Sample mean (men 13-26 years old in bandwidth) & & 0.040 \\
Sample mean for those enrolled in SR and in high-gang comuna & & \\
\hline
\end{tabular}

Panel B: Less Gang-Related Property Crimes

\begin{tabular}{lccc} 
Above Cutoff & -0.00263 & -0.00217 & -0.00205 \\
Reduced Form & $(0.00554)$ & $(0.00425)$ & $(0.00336)$ \\
& & & \\
Enrolled in SR & -0.00941 & -0.00772 & -0.00712 \\
No Covariates & $(0.0194)$ & $(0.0149)$ & $(0.0112)$ \\
& & & \\
Enrolled in SR & -0.0116 & -0.00872 & -0.00854 \\
Including pre-treatment covariates & $(0.0212)$ & $(0.0156)$ & $(0.0119)$ \\
& & & \\
Number of observations & 18,240 & 24,523 & 33,358 \\
$\begin{array}{l}\text { Sample mean (men 13-26 years old in bandwidth) } \\
\text { Sample mean for those enrolled in SR and in high-gang comuna }\end{array}$ & & 0.024 \\
\hline
\end{tabular}

Note: Standard errors in parentheses. ${ }^{* * *}$ significant at $1 \%{ }^{* *}$ significant at $5 \%{ }^{*}$ significant at $10 \%$. Tables report reduced form and two-staged least squares (2SLS) coefficients where the first stage is SR enrollment on being below the Sisben cutoff. The Sisben score is measured in 2002, and SR enrollment in 2005. We measure crime between 2005 and 2013. Regressions control linearly for the Sisben score, flexibly around the cutoff. We cluster standard errors by comuna. We consider only males between 21 to 26 years old in 2013. For regressions that have pre-treatment covariates, we include household characteristics, year of birth fixed effects, and neighborhood fixed effects. The sample excludes anybody whose first arrest was a violent or drug crime (Appendix Table A8 includes these observations as a robustness). 


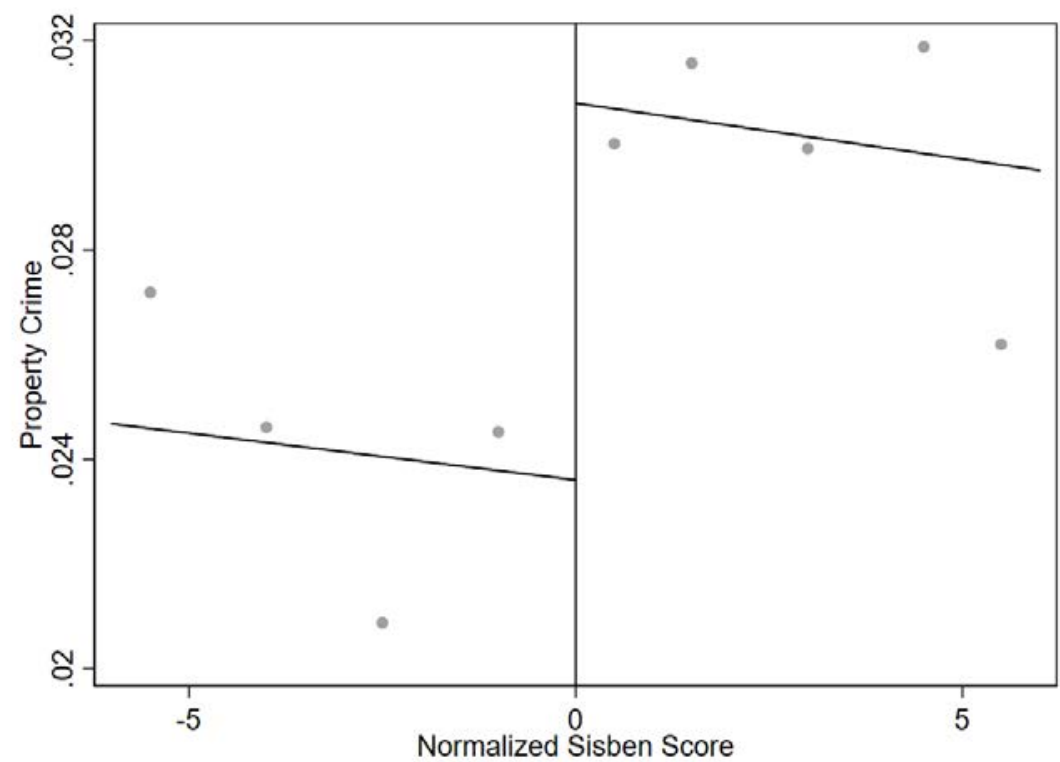

RD Graph using optimal binning procedure discussed in Calonico et al. (2014a). Normalized Sisben (2002) score on horizontal axis centered around cutoff. Higher values represent low scores (higher poverty).

with organized entities. Once again, our estimates are quite robust to the inclusion of control variables and the choice of the bandwidth, and our magnitudes are economically meaningful.

It is interesting to note that many of the less gang-related property crimes may also be income generating (even if they are not occupational choices), and as such it may be consistent with Becker (1968) if we found effects on them as well. Instead, we find that in this context, it is the decision to join a gang that seems to be the driving force. This is consistent with information the anthropological interviews, where gangs recruit idle youth, and joining a gang is very lucrative. The difference in coefficients between gang and less-gang related crimes are statistically significantly different for all bandwidths.

\subsection{Drug Crime}

The last type of crime involves the drug trade in Medellín. We analyze the impact on the probability to engage in drug-related crimes in Figure 5 and Table 6. Organized-crime related drug arrests include the manufacturing, distribution, and trafficking of hard drugs like cocaine and heroin. Drug crimes less likely to be related to organized entities include possession and consumption of drugs, as these are mostly indicative of personal recreational use, along with marijuana-related crimes. 
Table 6: Drug Crimes

\begin{tabular}{|c|c|c|c|c|}
\hline & Bandwidths: & 4 & 6 & 10 \\
\hline \multicolumn{5}{|c|}{ Panel A: More Gang-Related Drug Crimes } \\
\hline $\begin{array}{l}\text { Above Cutoff } \\
\text { Reduced Form }\end{array}$ & & $\begin{array}{c}0.00799 \\
(0.00721)\end{array}$ & $\begin{array}{c}0.00348 \\
(0.00492)\end{array}$ & $\begin{array}{c}0.00133 \\
(0.00458)\end{array}$ \\
\hline $\begin{array}{l}\text { Enrolled in SR } \\
\text { No Covariates }\end{array}$ & & $\begin{array}{c}0.0285 \\
(0.0240)\end{array}$ & $\begin{array}{c}0.0124 \\
(0.0169)\end{array}$ & $\begin{array}{l}0.00461 \\
(0.0155)\end{array}$ \\
\hline $\begin{array}{l}\text { Enrolled in SR } \\
\text { Including pre-treatment covariates }\end{array}$ & & $\begin{array}{c}0.0303 \\
(0.0270)\end{array}$ & $\begin{array}{c}0.0135 \\
(0.0180)\end{array}$ & $\begin{array}{l}0.00524 \\
(0.0159)\end{array}$ \\
\hline $\begin{array}{l}\text { Number of observations } \\
\text { Sample mean (men } 13-26 \text { years old } \\
\text { Sample mean for those enrolled in }\end{array}$ & $\begin{array}{l}\text { andwidth) } \\
\text { and in high-gar }\end{array}$ & 18,463 & 24,857 & $\begin{array}{c}33,851 \\
0.038 \\
0.045\end{array}$ \\
\hline
\end{tabular}

Panel B: Less Gang-Related Drug Crimes
Above Cutoff
$\begin{array}{ccc}-0.00976 & -0.0129 & -0.00788 \\ (0.00774) & (0.00798) & (0.00629)\end{array}$
Reduced Form
Enrolled in SR
$-0.0348 \quad-0.0458$
$-0.0274$
No Covariates
$(0.0280) \quad(0.0293)$
(0.0218)
Enrolled in SR
$\begin{array}{lll}-0.0385 & -0.0501 & -0.0277\end{array}$
$(0.0230)$
Including pre-treatment covariates
(0.0299) (0.0329)
Number of observations
$19,150 \quad 25,740 \quad 35,104$
Sample mean (men 13-26 years old in bandwidth)
0.073
Sample mean for those enrolled in SR and in high-gang comuna
0.088

Note: Standard errors in parentheses. ${ }^{* * *}$ significant at $1 \% ;^{* *}$ significant at $5 \%{ }^{*}$ significant at $10 \%$. Tables report reduced form and two-staged least squares (2SLS) coefficients where the first stage is SR enrollment on being below the Sisben cutoff. The Sisben score is measured in 2002, and SR enrollment in 2005. We measure crime between 2005 and 2013. Regressions control linearly for the Sisben score, flexibly around the cutoff. We cluster standard errors by comuna. We consider only males between 21 to 26 years old in 2013. For regressions that have pre-treatment covariates, we include household characteristics, year of birth fixed effects, and neighborhood fixed effects. The sample excludes anybody whose first arrest was a property or violent crime (Appendix Table A8 includes these observations as a robustness). 


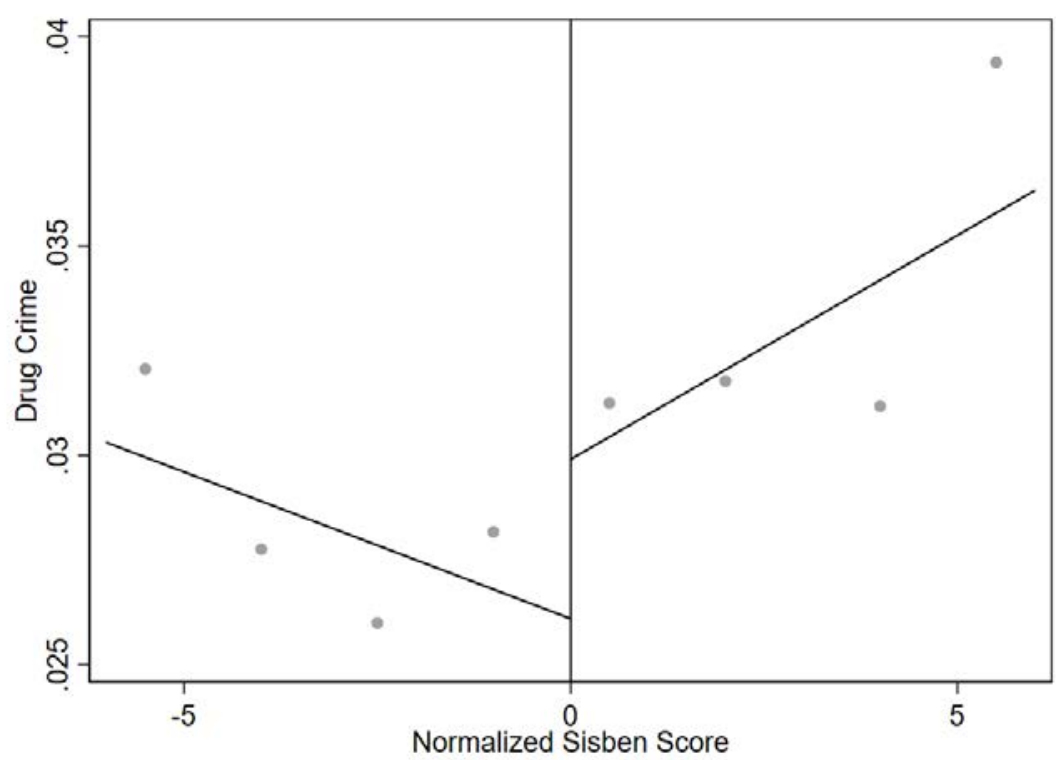

RD Graph using optimal binning procedure discussed in Calonico et al. (2014a). Normalized Sisben (2002) score on horizontal axis centered around cutoff. Higher values represent low scores (higher poverty).

In Figure 5, even though the discontinuity in drug crime arrests is visible, and there is a change in the slope of the relationship, the binned averages suggest a somewhat imprecise effect at the cutoff. In Table 6 the direction of effects are what we may expect, but our results are not precisely estimated. ${ }^{42}$ One possibility for the lack of precision is in the measurement error associated with the classification of such crimes: the difficulty in classifying possession of drugs as consumption or trafficking likely introduces noise. Indeed, offenses related to the trafficking of marijuana are problematic as small amounts of personal possession were made legal during this period. While homicides, assaults and theft produce clear evidence of crimes, encouraging an arrest, drug crimes are often difficult to detect and record. Not having any evidence of a crime actually being committed (e.g., a victim) may also allow authorities to under-report, especially if cartels pressure authorities to do so.

In sum, our results indicate that the drop in formal employment as a result of the subsidized benefits for informal workers raised the likelihood of being arrested for gang-related violent and property crimes. ${ }^{43}$ Even as health coverage is similar across the cutoff, the costs of being in

\footnotetext{
${ }^{42}$ In Appendix Table A9 we explore an alternative specification where we look at arrests conditional on not being in the 2009 formal sector. Here we have enough precision to measure a significant increase in gang-related drug crimes at the cutoff.

${ }^{43}$ Note that we measure post-treatment formal employment once in the twelve year period, but crime every year. Nevertheless, our formal employment result is also confirmed by a long literature showing similar results.
} 
the formal sector while maintaining coverage change discontinuously at the cutoff, prompting individuals to avoid the formal sector. As gang-crime is a lucrative option in the Medellín informal sector, we see a higher probability of arrests for gang-related crimes on one side of the cutoff.

The magnitudes of the estimated impacts are also economically meaningful. The pattern of results is similar but imprecise for drug crimes. Importantly, the results also show that non gang-related crimes of each type are not impacted by SR enrollment, ruling out many alternative mechanisms. In the following section, we investigate whether impacts are strongest in comunas that were historically associated with high organized crime activity as further evidence in support of our occupational choice interpretation.

\section{Heterogeneity, Specification Tests and Robustness}

\subsection{Heterogeneity by Comuna: the Importance of Neighborhoods}

Previous studies have emphasized that the opportunities in a neighborhood affect how easy it is to induce youth into crime (Kling et al., 2005). Understanding the heterogeneity by neighborhood helps us speak to much of the literature which relies on area-based variation. High crime neighborhoods may have more policing and higher detection rates that may lower the employment-crime elasticity, but may also have more opportunities to join a gang and thereby raise the elasticity.

We investigate if comunas with a high incidence of gangs demonstrate stronger impacts on gang-related arrests, at the RD cutoff. If the policy induces men to join organized crime, then we may expect that neighborhoods that have more such opportunities would have a larger impact. Figure A3 shows the spatial distribution of the locations where criminals were arrested in the act between 2005 and 2013, by type of crime. ${ }^{44}$

We select the five comunas with the highest number of gang members captured by the police, and create an indicator variable for whether individuals lived in these comunas in 2002,

\footnotetext{
${ }^{44}$ The red circle specifies the downtown of the city. In our main results we already show specifications that include neighborhood fixed effects, and we cluster errors at spatial levels larger than neighborhoods. Our results are robust to clustering at smaller spatial levels, like the neighborhood.
} 
Table 7: Heterogeneity by Comuna

\begin{tabular}{|c|c|c|c|c|}
\hline & Bandwidths: & 4 & 6 & 10 \\
\hline \multicolumn{5}{|c|}{ Panel A: Gang-Related Violent Crimes } \\
\hline Enrolled in SR & & $\begin{array}{c}0.0267^{* * * *} \\
(0.00892)\end{array}$ & $\begin{array}{l}0.0211^{* *} \\
(0.00914)\end{array}$ & $\begin{array}{c}0.0150^{* * *} \\
(0.00538)\end{array}$ \\
\hline Enrolled* Gang Comuna & & $\begin{array}{l}-0.00152 \\
(0.00464)\end{array}$ & $\begin{array}{c}0.0141^{* * *} \\
(0.00376)\end{array}$ & $\begin{array}{c}0.00563 \\
(0.00537)\end{array}$ \\
\hline F stat & & 90.2 & 154.6 & 232.9 \\
\hline Number of observations & & 18,052 & 24,272 & 33,027 \\
\hline
\end{tabular}

Panel B: Gang-Related Property Crimes

\begin{tabular}{lccc} 
Enrolled in SR & $0.0344^{* *}$ & $0.0273^{* *}$ & $0.0190^{*}$ \\
& $(0.0134)$ & $(0.0137)$ & $(0.0115)$ \\
Enrolled* Gang Comuna & 0.0282 & $0.0364^{* *}$ & $0.0258^{* *}$ \\
& $(0.0209)$ & $(0.0167)$ & $(0.0116)$ \\
& & & \\
F stat & 86.7 & 145.5 & 249.6 \\
Number of observations & 18,426 & 24,740 & 33,625 \\
\hline
\end{tabular}

Panel C: Gang-Related Drug Crimes

\begin{tabular}{lccc} 
Enrolled in SR & 0.0282 & 0.0131 & 0.00296 \\
& $(0.0248)$ & $(0.0177)$ & $(0.0166)$ \\
Enrolled* Gang Comuna & 0.000310 & -0.00590 & 0.00690 \\
& $(0.0136)$ & $(0.0135)$ & $(0.0129)$ \\
& & & \\
F stat & 96 & 149.1 & 201.7 \\
Number of observations & 18,463 & 24,857 & 33,851 \\
\hline
\end{tabular}

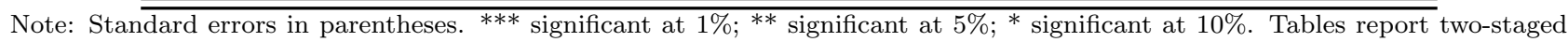
least squares (2SLS) coefficients where the first stage is SR enrollment on being below the Sisben cutoff and an interaction between high-gang comunas and being below the cutoff. The Sisben score is measure in 2002, SR enrollment in 2005, and crime outcomes are measured between 2005 and 2013. Regressions include comuna fixed effects and an interaction between high-gang comunas and indicators for SR enrollment. Regressions control linearly for the Sisben score, flexibly around the cutoff. We consider only males between 21 to 26 years old in 2013 . We cluster errors by comuna. The mean arrest rate across all five gang comunas are $18 \%$, which is also the mean arrest rate in non-gang comunas. See Appendix Table A5 for the less gang related crimes. 
our baseline year. ${ }^{45}$ These are not necessarily high crime areas, as the mean arrest rates for young men is $18 \%$ in both gang and non-gang comunas . Yet, gang crimes make up $43 \%$ of arrests in gang comunas, and 37\% of arrests in non-gang comunas .

We interact this variable with the cutoff to analyze the heterogeneity in effects by arealevel gang activity. Table 7 presents the results. Since we have an interaction term, we report the IV first stage F-statistics as well. The effects on crime are present in both high and low gang-activity areas, but for property crime are larger in areas that have more gang activity. For violent crime the interaction term is strongly positive for only one of the bandwidths. This suggests that opportunities present in the neighborhood affect the likelihood of inducement into organized property crime at the cutoff.

In Appendix Table A5 we show the results for less gang related crimes. Once again, there is no evidence of SR enrollment being associated with less gang-related crimes in either the gang comunas or the non-gang comunas. Notice, it is not that our identification strategy protects against any increases in policing activity in gang comunas, as we are comparing one side of the Sisben cutoff to the other. Additionally, our main tables all show a row of results that also include comunas fixed effects.

\subsection{Density Tests and Balance Tests}

In our study, identification relies on the assumption that all other determinants of the outcome vary smoothly at the cutoff. We show that an extensive set of observables display no systematic patterns in discontinuities. In Tables A3 and A4, we show that baseline characteristics from 2002 (three years before our crime data begins) are balanced for the entire sample and for the sample used in the regressions (young males), respectively. We consider two sets of baseline characteristics: one for household-level socioeconomic variables, and the other for individuals. We report estimates over the range of different bandwidths used in our main analysis: between 4 and 10 points around the cutoff. We find no evidence of systematic discontinuities in covariates at the threshold. In the first row of Tables A3 and A4, we report a summary measure in which we collapse these variables by taking their first principal component and repeat the same

\footnotetext{
${ }^{45}$ The top five are chosen on the criteria of having the most gang-flags as a ratio of total crimes.
} 
RD analysis that we do for our main results. Again, there is no detectable difference in this composite measure of baseline characteristics, even for the largest bandwidth of 10 .

Additionally, for the empirical strategy to be valid, households must not be able to manipulate their score to cross the cutoff. Work by Camacho and Conover (2011) highlights politically motivated manipulation in certain municipalities in other parts of Colombia where elections were being held. This includes both under-reporting of wealth (not necessarily a threat to our design), but also manipulation of the final score. In other parts of the country the 1998 mayoral elections (years before our sample begins) show evidence of manipulation. We use the raw survey data and the 2002 Sisben score only for Medellín, and so are less concerned about any manipulation of the final score. ${ }^{46}$ Indeed, our tests of balance in the large set of baseline characteristics of the household are indicative of a lack of systematic manipulation in this context. Importantly, the cutoff for SR eligibility was determined well after the 2002 Sisben scores were released, and as such the cutoffs were not known to anybody during the survey. As such, we are confident that nobody could manipulate the 2002 score, even if they joined a life of crime in later years.

We test whether there was a discontinuity in the density of scores at the cutoff for the particular context of Medellín after 2002. We do this by following two methods used in the literature: the McCrary (2008) test and a test recently developed by Cattaneo et al. (2017). The Cattaneo et al. (2017) test yields a conventional t-statistic of 0.0489 or a p-value of 0.961 , and a robust bias corrected p-value of 0.940 , confirming that there is no statistically detectable evidence of manipulation. Figure A4 shows the distribution of the Sisben score for males (non-criminals and criminals) and conducts a McCrary (2008) test. Note that the distribution appears to be smooth with no evidence of bunching before the cutoff between Sisben levels 2 and 3 (red line).

\footnotetext{
${ }^{46}$ The timing of the Sisben surveys do not coincide with the Medellín mayoral elections, which is when some evidence of manipulation was found in other parts of the country.
} 


\subsection{Alternative Crime Classifications, Different Bandwidths, Spec- ifications and Subsamples, and the Nonparametric RD}

We conduct a number of robustness checks. First, we re-classify crimes into gang-related and non gang-related groups based on the location where these types of crimes are more likely to occur. We calculate the relative propensity of each crime in each neighborhood. The crimes that have a higher propensity to take place in neighborhoods that were traditionally associated with organized crime are classified as gang-related crimes. These are neighborhoods that also have the highest proportion of gang-related flags associated with them. To be specific, we sort the crimes by the fraction of first arrests that happen in a gang-neighborhood. The top half of this list is classified as gang-related crimes.

This 'Neighborhood Classification Method' of crimes produces a list similar to the one where we use the police generated flags, with minor differences. ${ }^{47}$ The lists of the top prevalent crimes by classification method can be found in Appendix Table A1. In Table A6, we re-examine our main results using the alternative classification for gang-related crimes. These results are similar to before, with the added statistical significance of drug crimes under some specifications.

Next, we re-examine our main results using the bias-correction methods suggested by Calonico et al. (2014a). In Table A7, we show results that conduct a polynomial bias correction at a larger bias-correction bandwidth (reported in the table). Once again, our results show an economically and statistically significant increase in gang-related violent and property crimes, but the effects on drug crimes are small and imprecise.

In our main specifications, when looking at a specific type of crime, we exclude arrests from other crimes. ${ }^{48}$ In the specification shown in Table A8 we include the other categories along with the non-criminals, and show that results are similarly robust.

As our story is about both non-formal employment and violent crime, we present a specification in Table A9 that simultaneously captures both. The advantage of our individual-level data is that we can measure both employment and criminal behavior for the same individual.

\footnotetext{
${ }^{47}$ The big differences among the top 25 crimes is with 'conspiracy to commit murder' that is classified as gang-related under the original classification but not gang-related under the neighborhood definition. Outside the top 25 there are other differences in the definition.

${ }^{48}$ For instance, when studying violent crimes, we exclude property and drug crimes from the sample altogether.
} 
However, since we do not have annual data on formal employment, we use the 2009 Sisben to measure formal employment. Here the dependent variable is an indicator that equals one when the individual was not formally employed and arrested for a crime. Our results again show an increase in gang-related criminal activity, with even the drug crimes now being economically and statistically significant. This result allows us to address any concerns that the increase in informality and increase in arrests were independent of each other.

Finally, in Figure A5 we vary the bandwidth through a much wider range - every integer between 2 and 10. Gang-relates violent and property crimes consistently display a positive RD coefficient, whereas drug crimes are not statistically indistinguishable from zero, even as the coefficients are positive and fairly large for smaller bandwidths.

\section{Interpretation and Alternative Mechanisms}

The simultaneous decrease in formal sector employment and rise in arrests related to organized crime supports a model in which a higher cost of being formally employed induces an occupational choice into a life of crime (Becker, 1968). ${ }^{49}$ Indeed, using the 2009 Sisben measures, we show in Table A9 that there was an increase in individuals that were simultaneously not in the formal sector and arrested. This result is statistically and economically significant for all gang crimes, including drug crimes, and validates the interpretation of our results as being driven by individual-level occupational choice across formal employment and potentially criminal activity in the informal sector. Given the lack of effects for non gang-related crimes, it is difficult to find alternative explanations to reconcile these results.

We consider three alternative theories. First, better health benefits at the cutoff may induce one to engage in riskier behaviors, yet it is difficult to support why these riskier behaviors would not also include non gang-related crimes (e.g., drug consumption). Furthermore, as health coverage is near universal by the end of this period, individuals on both sides of the cutoff have the same coverage, with the only difference being who pays (which depends on formal sector employment). Indeed, the benefits themselves are quite comparable for most of this period, and

\footnotetext{
${ }^{49}$ While we do not discuss in detail specific pathways, anthropological evidence lends credence to active recruitment by gang members of young men that 'hang around' in neighborhoods with idle time, and are not in the formal sector (Baird, 2011).
} 
as such there are no discontinuities in healthcare at the cutoff. This suggests that the driving force is the cost of coverage under formal sector employment.

Second, formal workers vesting more into the health system may fear losing their jobs if arrested and reduce criminal activities as a result. However, again this should be just as true for non gang-related crimes. Third, the police may falsely target informal workers even if they are not criminals, but it is unlikely that they would be booked disproportionately under gangrelated crimes. Indeed, it may be easier to falsely target potential criminals for petty crime rather than more serious offenses like homicide or auto theft. The distinction between gang and non-gang crimes powerfully helps exclude alternative mechanisms and lends credence to the occupational choice story we posit.

We find that a 1 percentage point fall in formal employment is related to $3.1 \%$ increase in arrests, which lies in the lower range of recently reviewed estimates. ${ }^{50}$ Our estimates reflect slight differences with other estimates in the literature. Becker (1968) discusses both income and substitution effects when wages rise in one sector. For much of the other literature, job loss or unemployment in the formal sector may produce income and substitution effects that both accentuate criminal activity. In contrast, we may think that the gains from the subsidy in our case may actually reduce criminal activity. Additionally, while we are directly testing the choice of occupation, most of the related work studies reduced access to legitimate jobs as a consequence of job losses or work restrictions, and thereby recover different elasticities. ${ }^{51}$

As our estimates are similar to those obtained from other recent causal analysis leveraging individual-level variation (Pinotti, 2017), we interpret our results to be not only economically meaningful, but also plausible. Yet, these magnitudes should be understood to be contextspecific. We study a high-crime environment, similar only to other developing countries and especially Latin America. ${ }^{52}$ Furthermore, we estimate a Local Average Treatment Effect (LATE) on marginal workers in the neighborhood of an income cutoff. It is plausible that at higher income levels, healthcare is a less important fraction of expenditures, and is less likely to in-

\footnotetext{
${ }^{50} \mathrm{~A}$ recent review by Bennett and Ouazad (2018) discusses how a 1 percentage point increase in unemployment usually corresponds to a $3-7 \%$ increase in crime.

${ }^{51}$ Job losses and structurally imposed employment restrictions may additionally induce effects on depression, subsequent job search, social stigma etc. whereas our variation in relative costs of employment should not.

${ }^{52}$ Recent evidence from Latin America suggests much larger employment-crime elasticities (Dell et al., 2018; Dix-Carneiro et al., 2018).
} 
duce such behavior. Finally, it should be noted that the newly induced marginal criminals may be unlike the average criminal along many dimensions, including ease of avoiding arrests, and as such our results may not be widely generalizable for other sub-populations. Nevertheless, since the exogenous probability of getting caught conditional on committing a crime has no reason to be discontinuous at the cutoff, our estimates are unbiased even in the presence of such heterogeneity in criminal "skill."

\section{Conclusion}

In this paper, we highlight an important fact: disincentivizing formal employment can lead to substantial increases in criminal activity when informal opportunities include employment by organized criminal entities. We evaluate this claim in the context of the high-crime environment of Medellín, Colombia. We first provide strong evidence showing that the criteria behind the health benefits policy led to a sharp decrease in formal sector employment. At the margin, the policy raised the opportunity cost of formal-sector employment and induced workers to join the informal labor market.

In Medellín, this informal market contains significant opportunities related to organized crime. We follow these same individuals over a decade and show that this decrease in formal sector employment led to an increase in the probability of being arrested for organized-crime related activities. On the other hand, crimes less likely to be associated with criminal economic enterprises, like crimes of impulse or opportunity, show no such impacts at the eligibility threshold, lending credence to the occupational choice mechanism we advance. Together, our simple calculations suggest that as the policy pushed workers out of the formal sector, a meaningful fraction of these workers were drawn into organized crime. These effects were largest in neighborhoods that had, at baseline, greater opportunities to join organized crime.

Crime deterrence may have limited benefits if the supply elasticity to criminal activity is high (Freeman, 1999). Investigating the decisions behind choosing a life of crime, as we do here, is essential in the fight against crime. Importantly, our work speaks to the determinants of engaging in criminal activity at the individual level. The strength of our approach is that we do not need to use area-based variation or disequilibrium shocks like job-losses to identify the 
occupation choice between individual employment opportunities and crime. We do this using a unique data set that matches the census of arrests with socio-economic outcomes over a decade, in the context of one of the most violent cities in the world. We find a source of exogenous variation generated by policy rules, and use a regression discontinuity design to estimate our effects.

We conclude that Colombia's well-intentioned and broad-based subsidies for healthcare had the unintended consequence of incentivizing gang participation by way of its distortionary provision rules. The program being important for providing subsidized health access to low income families implies that there is little reason to do away with it. Yet, the formality-clause governing the selection into the program may be distortionary, and as such warrant further examination..$^{53}$

Removing the emphasis on informality (but still targeting the poor) may negate the increase in criminal activity around the cutoff. The costs underlying such a change would be a larger fiscal burden as even low-income formal sector workers would be eligible for SR. The benefits, on the other hand, are far reaching: less crime, less policing and incarceration, and less negative externalities on families and children. This has important welfare implications for the design of many such programs across the developing world which often have far-reaching and understudied consequences on seemingly unrelated outcomes and behaviors. Our results provide guidance for how impactful improving access to and incentives for formal sector employment can be for deterring criminal activity.

\footnotetext{
${ }^{53}$ Recognizing these adverse effects, policy-makers lowered the costs of CR enrollment at the end of our study period, when Law 1607 was enacted, leading to a significant increase in formal sector employment (Bernal et al., 2017; Kugler et al., 2017; Morales and Medina, 2017).
} 


\section{References}

Agan, A. and M. Makowsky (2018). The Minimum Wage, EITC, and Criminal Recidivism. Working paper.

Alesina, A., S. Piccolo, and P. Pinotti (2017). Organized Crime, Violence, and Politics. NBER Working Paper.

Arteaga, C. (2019). The Cost of Bad Parents: Evidence from the Effects of Parental Incarceration on Children's Education. Working Paper.

Attanasio, O., A. Guarín, C. Medina, and C. Meghir (2017). Vocational Training for Disadvantaged Youth in Colombia: A Long-Term Follow-up. American Economic Journal: Applied Economics 9(2), 131-43.

Baird, A. (2011). Negotiating Pathways to Manhood: Violence Reproduction in Medellin's Periphery. Thesis, University of Bradford.

Barnwal, P. (2018). Curbing Leakage in Public Programs: Evidence from India's Direct Benefit Transfer Policy. Mimeo.

Becker, G. S. (1968). Crime and Punishment: An Economic Approach. Journal of Political Economy 76(2), 169-217.

Bennett, P. and A. Ouazad (2018). Job Displacement, Unemployment, and Crime: Evidence from Danish Microdata and Reforms. Journal of the European Economic Association. forthcoming.

Berk, R., K. Lenihan, and P. Rossi (1980). Crime and poverty: Some experimental evidence from ex-offenders. American Sociological Review.

Bernal, R., M. Eslava, M. Melendez, and A. Pinzon (2017). Switching from Payroll Taxes to Corporate Income Taxes: Firms' Employment and Wages after the Colombian 2012 Tax Reform. Inter-American Development Bank No. 1268.

Bhuller, M., G. Dahl, K. Loken, and M. Mogstad (2018). Incarceration, Recidivism and Employment. NBER Working Paper No. 22648.

BJS, U. B. o. J. S. (1994). Sourcebook of Criminal Justice Statistics. University at Albany.

Blattman, C. and J. Annan (2015). Can Employment Reduce Lawlessness and Rebellion? A Field Experiment with High-Risk Men in a Fragile State. American Political Science Review 10(1), 1-17.

Blattman, C., G. Duncan, L. Benjamin, and S. Toben (2018). Gangs of Medellín: How Organized Crime is Organized. Technical report.

Blattman, C., D. Green, D. Ortega, and S. Tobón (2017). Place-based Interventions at Scale: The Direct and Spillover Effects of Policing and City Services on Crime. Technical report.

Bloom, D. (2006). Employment-focused programs for ex-prisoners: What have we learned, what are we learning, and where should we go from here? ERIC. 
Buonanno, P. and J. Vargas (2018). Inequality, crime, and the long run legacy of slavery. Journal of Economic Behavior and Organization. forthcoming.

Calonico, S., M. Cattaneo, and R. Titiunik (2014a). Robust Data-Driven Inference in the Regression Discontinuity Design. Stata Journal 14(4), 909-946.

Calonico, S., M. Cattaneo, and R. Titiunik (2014b). Robust Nonparametric Confidence Intervals for Regression-Discontinuity Designs. Econometrica 82(6), 2295-2326.

Camacho, A. and E. Conover (2011). Manipulation of Social Program Eligibility. American Economic Journal: Economic Policy 3(2), 41-65.

Camacho, A., E. Conover, and A. Hoyos (2014). Effects of Colombia's Social Protection System on Workers' Choice between Formal and Informal Employment. World Bank Economic Review 28(3), 446-466.

Cattaneo, M., M. Jansson, and X. Ma (2017). Simple Local Regression Distribution Estimators with an Application to Manipulation Testing. Mimeo Michigan.

CCSPJP (2009). Consejo Ciudadano para la Seguridad Publica y la Justicia Penal.

Chimeli, A. B. and R. R. Soares (2017). The use of violence in illegal markets: Evidence from mahogany trade in the brazilian amazon. American Economic Journal: Applied Economics 9(4), 30-57.

Chioda, L., J. De Mello, and R. R. Soares (2016). Spillovers from Conditional Cash Transfer Programs: Bolsa Familia and Crime in Urban Brazil. Economics of Education Review 54, 306-320.

Cornwell, C. and W. N. Trumbull (1994). Estimating the Economic Model of Crime with Panel Data. Review of Economics and Statistics 76(2), 360-366.

Cortes, D., J. Santamaria, and J. Vargas (2016). Economic shocks and crime: Evidence from the crash of ponzi schemes. Journal of Economic Behavior and Organization 131, 263-275.

Cullen, J. B., B. A. Jacob, and S. D. Levitt (2005). The Impact of School Choice on Student Outcomes: An Analysis of the Chicago Public Schools. Journal of Public Economics 89(6), 729-60.

Cullen, J. B., B. A. Jacob, and S. D. Levitt (2006). The Effect of School Choice on Participants: Evidence from Randomized Lotteries. Econometrica 74(5), 1191-1230.

Cullen, J. B. and S. D. Levitt (1999). Crime, Urban Flight, and the Consequences for Cities. The Review of Economics and Statistics 81(2), 159-169.

Dell, M., B. Feigenberg, and K. Teshima (2018). The Violent Consequences of Trade-Induced Worker Displacement in Mexico. American Economic Review: Insights forthcoming.

DellaVigna, S. and D. M. Paserman (2005). Job Search and Impatience. Journal of Labor Economics 23(3), 527-588.

DiTella, R., S. Galiani, and E. Schargrodsky (2010). Crime distribution and victim behavior during a crime wave. In The economics of crime: Lessons for and from Latin America, pp. 175-204. University of Chicago Press. 
DiTella, R. and E. Schargrodsky (2013). Criminal Recidivism After Prison and Electronic Monitoring. Journal of Political Economy 121(1), 28-73.

DiTella, R. and E. Schargrodsky (2014). Do Police Reduce Crime? Estimates Using the Allocation of Police Forces After a Terrorist Attack. American Economic Review 94(1), 115-33. March.

Dix-Carneiro, R., R. Soares, and G. Ulyssea (2018). Economic Shocks and Crime: Evidence from the Brazilian Trade Liberalization. American Economic Journal: Applied Economics forthcoming.

Doyle, C. (2016). Explaining Patterns of Urban Violence in Medellin, Colombia. Laws 5(3).

Doyle, J. (2008). Child Protection and Adult Crime. Journal of Political Economy 116(4), $746-770$.

Doyle, J. J. (2007). Child Protection and Child Outcomes: Measuring the Effects of Foster Care. American Economic Review 97(5), 1583-1610.

Dustmann, C. and A. P. Damm (2014). Does Growing Up in a High Crime Neighborhood Affect Youth Criminal Behavior? American Economic Review 104(6), 1806-1832.

Ehrlich, I. (1973). Participation in Illegitimate Activities: A Theoretical and Empirical Investigation. Journal of Political Economy 81(3), 521-565.

Entorf, H. (2000). Socioeconomic and Demographic Factors of Crime in Germany: Evidence from Panel Data of the German States. International Review of Law and Economics 20(1), 75-106.

Feler, L. and M. Z. Senses (2017). Trade Shocks and the Provision of Local Public Goods. American Economic Journal: Economic Policy 9(4), 101-43.

Fella, G. and G. Gallipoli (2014). Education and Crime over the Life Cycle. The Review of Economic Studies 81(4), 1484-1517.

Fernández, C. and L. Villar (2017). The Impact of Lowering the Payroll Tax on Informality in Colombia. Economía 18(1), 125-155.

Ferraz, C. and F. Finan (2008). Exposing Corrupt Politicians: The Effects of Brazil's Publicly Released Audits on Electoral Outcomes. The Quarterly Journal of Economics 123(703-745), 2 .

Ferraz, C. and F. Finan (2011). Electoral Accountability and Corruption: Evidence from the Audit Reports of Local Governments. American Economic Review 101(4), 1274-1311.

Foley, C. F. (2011). Welfare Payments and Crime. Review of Economics and Statistics 93(1), $97-112$.

Fougere, D., F. Kramarz, and J. Pouget (2009). Youth Unemployment and Crime in France. Journal of the European Economic Association 7(5), 909-938.

Freeman, R. B. (1999). The Economics of Crime. Handbook of Labor Economics 3(c). edited by O. Ashenfelter and D. Card. Elsevier Science. 
Gaviria, A., C. Medina, and C. Mejia (2007). Assessing Health Reform in Colombia: From Theory to Practice. Economia $7(1)$.

Golsteyn, B. H., H. Grönqvist, and L. Lindahl (2014). Adolescent Time Preferences Predict Lifetime Outcomes. The Economic Journal 124, F739-F761.

Gould, E. D., B. A. Weinberg, and D. B. Mustard (2002). Crime Rates and Local Labor Market Opportunities in the United States: 1979-1997. The Review of Economics and Statistics $84(1), 45-61$.

Greenbaum, R. T. and G. E. Tita (2004). The Impact of Violence Surges on Neighborhood Business Activity. Urban Studies 13, 2495-2514.

Grogger, J. (1995). The Effect of Arrests on the Employment and Earnings of Young Men. Quarterly Journal of Economics 110(1), 51-72.

Grogger, J. (1998). Market Wages and Youth Crime. Journal of Labor Economics 16, 756-791.

Gronqvist, H. (2017). Youth Unemployment and Crime: Lessons from Longitudinal Population Records. Mimeo.

Hahn, J., P. Todd, and W. van der Klaauw (2001). Identification and Estimation of Treatment Effects with a Regression Discontinuity Design. Econometrica 69(1), 201-209.

Heller, S. (2014). Summer Jobs Reduce Violence among Disadvantaged Youth. Science $346(6214), 1219-1223$.

Ihlanfeldt, K. (2007). Neighborhood Drug Crimes and Young Males Job Accessibility. The Review of Economics and Statisticsc 89(1), 151-164.

Imbens, G. W. and K. Kalyanaraman (2012). Optimal Bandwidth Choice for the Regression Discontinuity Estimator. The Review of Economic Studies 79(3), 933-959.

Joumard, I. and J. Londono (2013). Income Inequality and Poverty in Colombia: The Role of the Labour Market. OECD Economics Department Working Papers No. 1036 (1).

Karin, E. (2005). Unemployment and Crime: Is There a Connection? Scandinavian Journal of Economics 107(2), 353-373.

Kearney, M. S., B. Harris, E. Jacome, and L. Parker (2014). Ten Economic Facts about Crime and Incarceration in the United States. The Hamilton Project Policy Memo. Brookings Institute.

Kemple, J., F. Doolittle, and J. Wallace (1993). The National JTPA Study: Final Implementation Report. New York: Manpower Demonstration Research Corporation.

Kling, J. (2006). Incarceration Length, Employment, and Earnings. American Economic Review.

Kling, J., J. Ludwig, and L. Katz (2005). Neighborhood Effects on Crime for Female and Male Youth: Evidence from a Randomized Housing Voucher Experiment. The Quarterly Journal of Economics 120(1), 87-130. 
Kling, J. R., J. B. Liebman, and L. F. Katz (2007). Experimental Analysis of Neighborhood Effects. Econometrica 75(1), 83-119.

Kugler, A. and M. Kugler (2009). Labor Market Effects of Payroll Taxes in Developing Countries: Evidence from Colombia. Economic Development and Cultural Change 57(2), 335-358.

Kugler, A., M. Kugler, and L. Herrera Prada (2017). Do Payroll Tax Breaks Stimulate Formality? Evidence from Colombia's Reform. NBER Working Paper No. 23308.

Lamprea, E. and J. Garcia (2016, December). Closing the Gap Between Formal and Material Health Care Coverage in Colombia. Health and Human Resources Journal.

Lin, M.-J. (2008). Does Unemployment Increase Crime? Evidence from U.S. Data 1974-2000. Journal of Human Resources 43(2), 413-436.

Lochner, L. (2004). Education, Work, and Crime: A Human Capital Approach. International Economic Review 45(3), 811-43.

Lochner, L. and E. Moretti (2004). The Effect of Education on Crime: Evidence from Prison Inmates, Arrests, and Self-Reports. American Economic Review 94 (1).

Lott, J. (1992). An Attempt at Measuring the Total Monetary Penalty from Drug Convictions: The Importance of an Individual's Reputation. Journal of Legal Studies 29, 159-187.

Machin, S. and C. Meghir (2004). Crime and Economic Incentives. Journal of Human Resources 39(4), 958-979.

McCrary, J. (2008). Manipulation of the Running Variable in the Regression Discontinuity Design: A Density Test. Journal of Econometrics 142(2), 698-714.

Medina, C. and J. Tamayo (2011). An Assessment of How Urban Crime and Victimization Affects Life Satisfaction. in Dave, Webb and Eduardo, Wills-Herrera (Eds.), Subjective Well-Being and Security. Springer, Social Indicators Research Series.

Melnikov, N., C. Schmidt-Padilla, and M. M. Sviatschi (2019). Gangs, labor mobility, and development. Working Paper.

Morales, L. and C. Medina (2017). Assessing the Effect of Payroll Taxes on Formal Employment: The Case of the 2012 Tax Reform in Colombia. Economia Journal 0, 75-124. LACEA.

Mustard, D. B. (2010). How Do Labor Markets Affect Crime? New Evidence on an Old Puzzle. IZA Discussion Paper (4856).

Olken, B. and R. Pande (2012). Corruption in Developing Countries. Annual Review of Economics 4 (1), 479-509.

Pinotti, P. (2017). Clicking on Heaven's Door: The Effect of Immigrant Legalization on Crime. American Economic Review 107(1), 138-168.

Raphael, S. and R. Winter-Ember (2001). Identifying the Effect of Unemployment on Crime. Journal of Law and Economics 44(1), 259-283. 
Rose, E. (2019). The Effects of Job Loss on Crime: Evidence From Administrative Data. Working Paper.

Rozema, R. (2018). Urban DDR-processes: Paramilitaries and Criminal Networks in Medellin, Colombia. Journal of Latin American Studies 40, 423-452.

Santamaria, M., F. Garcia, and A. V. Mujica (2008). Los Costos No Laborales y el Mercado Laboral: Impacto de la Reforma de Salud en Colombia. Working Paper 43. Fedesarrollo, Bogota, Colombia.

Schochet, P., J. Burghardt, and S. McConnell (2008). Does job corps work? impact findings from the national job corps study. American Economic Review 98(5), 1864-1886.

Sviatschi, M. M. (2018). Making a Narco: Childhood Exposure to Illegal Labor Markets and Criminal Life Paths. Working paper.

Yang, D. (2008). Can Enforcement Backfire? Crime Displacement in the Context of Customs Reform in the Philippines. Review of Economics and Statistics 90(1), 1-14. 


\section{Online Appendix: Additional Tables and Figures}

Figure A1: Timeline of Data Used

Arrests (SIJIN)

$\begin{array}{ccc} & & \\ 2002 & 2005 & 2009 \\ \text { Sisben Score } / & \text { Subsidized } & \text { Formal } \\ \text { Eligibility } & \text { Regime } & \text { Employment } \\ \text { (Sisben } 1, & \text { (Sisben } 2, & \text { (Sisben 3, } \\ \text { DNP) } & \text { DNP) } & \text { DNP) }\end{array}$

Figure A2: Distribution of Age at Arrest (Males)

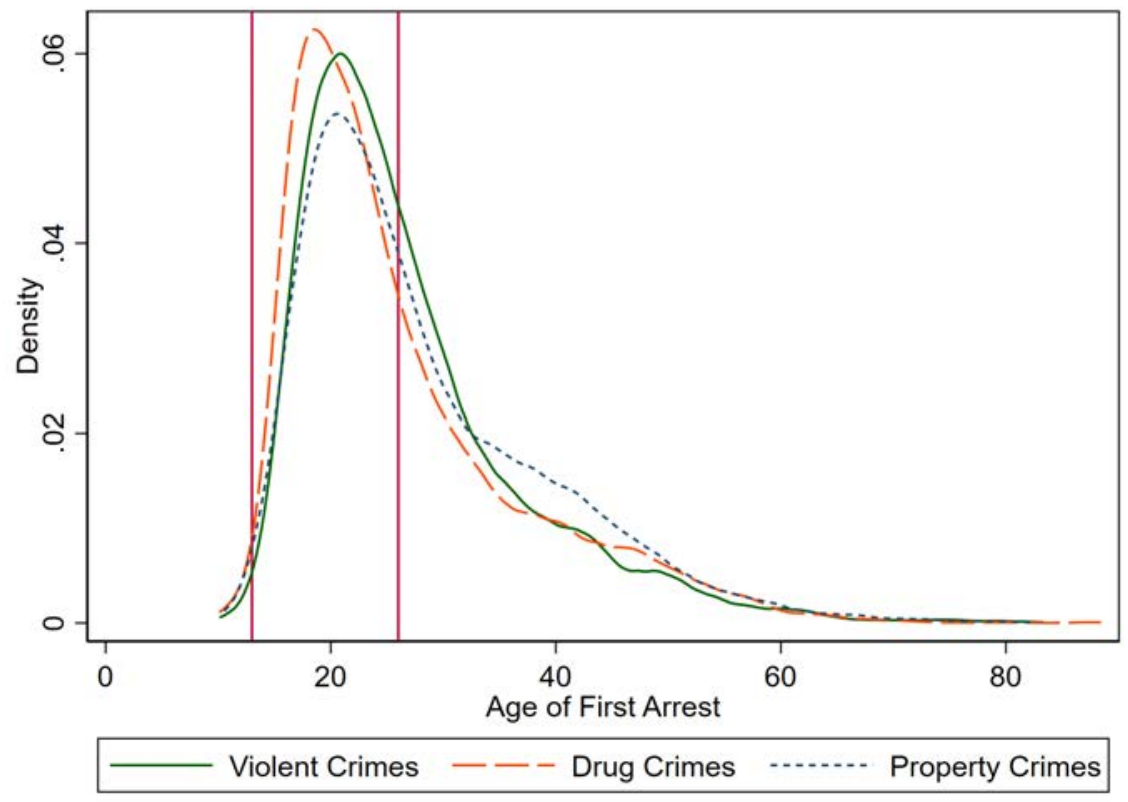

Source: Policía Nacional de Colombia. Vertical lines represent ages 13 and 26. 
Figure A3: Location of 'in-the-act' arrests by type of crime, 2005-2013.
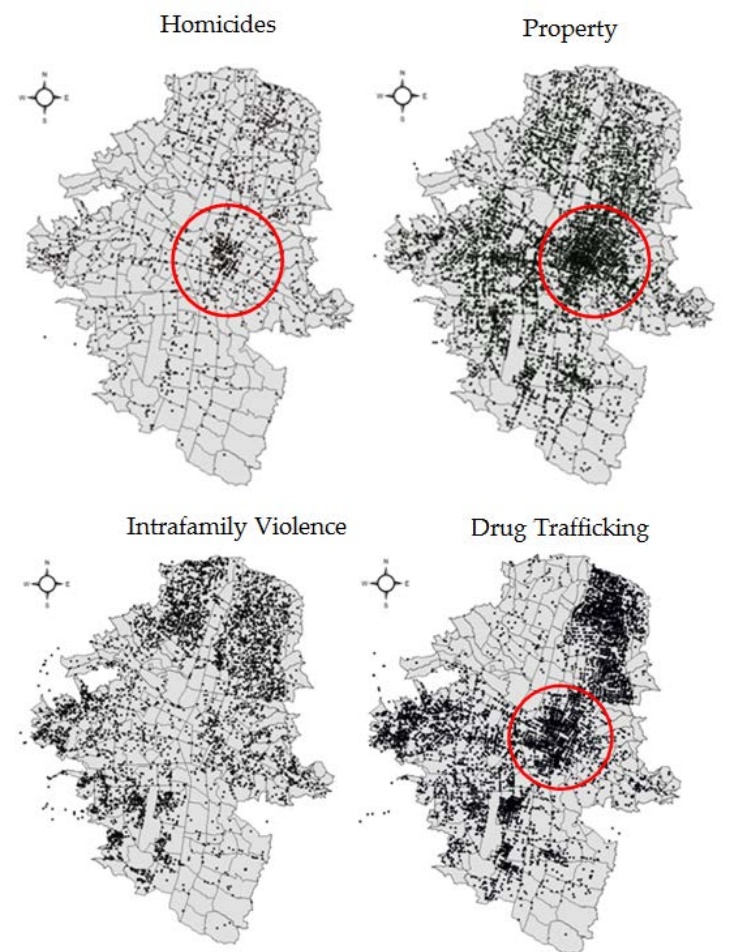

Source: Medina and Tamayo (2011) using Policía Nacional de Colombia. Dots indicate arrests. Bold lines are neighborhood boundaries. Red circle is downtown. 
Figure A4: Sisben score Distribution (All Males).
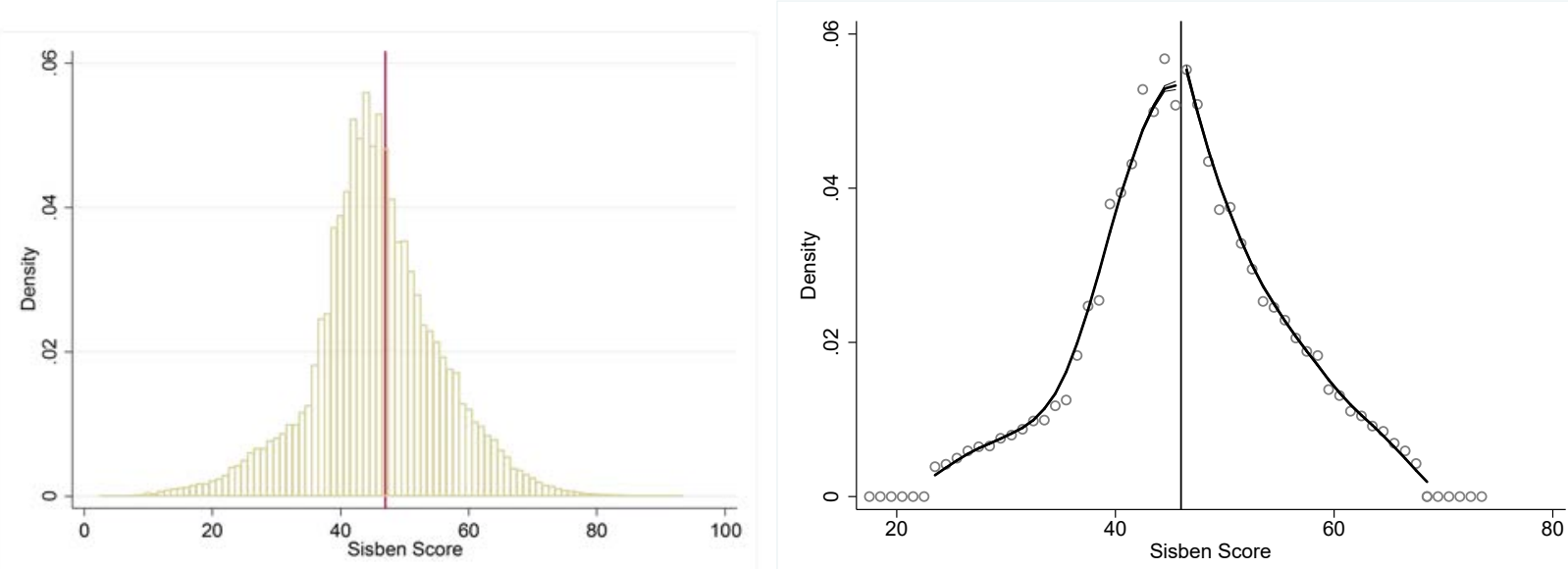

Source: Sisben survey of 2002. The figure includes all males (i.e. both non-criminals and arrested individuals). The left panel shows the histogram and the right panel conducts a McCrary (2008) test. 
Table A1: List of Top Crimes by Data-driven Classifications

\begin{tabular}{|c|c|c|c|}
\hline Crime & Type & Gang Flags & Neighborhood Method \\
\hline Drug Consumption / Possession & Drug & No & No \\
\hline Drug trafficking / Distribution - Marijuana & Drug & No & No \\
\hline Drug trafficking / Distribution & Drug & Yes & Yes \\
\hline Drug trafficking / Distribution - Cocaine paste & Drug & Yes & Yes \\
\hline Drug trafficking / Distribution Heroin & Drug & Yes & Yes \\
\hline Use of Fake Identification, false document & Property & No & No \\
\hline Motor vehicle theft (Motorcycles) & Property & No & No \\
\hline Receiving Bribes (as officials) & Property & No & No \\
\hline Copyright/Fraud & Property & No & No \\
\hline Identity Theft & Property & No & No \\
\hline Fraud & Property & No & No \\
\hline Theft / Assault & Property & Yes & Yes \\
\hline Robbery (To Businesses, firms) & Property & Yes & Yes \\
\hline Property Vandalism & Property & Yes & Yes \\
\hline Motor Vehicle Theft - Cars & Property & Yes & Yes \\
\hline Burglary & Property & Yes & Yes \\
\hline Simple Assault/Battery & Violent & No & No \\
\hline Rape/Sexual Assault & Violent & No & No \\
\hline Conspiracy to commit murder & Violent & Yes & No \\
\hline Homicide & Violent & Yes & Yes \\
\hline Extortion & Violent & Yes & Yes \\
\hline Assault / Battery - Against Police & Violent & Yes & Yes \\
\hline Manufacture, Trafficking Firearms / Weapons & Violent & Yes & Yes \\
\hline Intimidation and Stalking & Violent & Yes & Yes \\
\hline Terrorism & Violent & Yes & Yes \\
\hline Kidnapping & Violent & Yes & Yes \\
\hline
\end{tabular}

List of top crimes by type and gang classification, out of 103 crimes. The 'Gang Flags' lists whether or not the crime has a high propensity to receive a police reported flag of gang-related at the time of arrest. The 'Neighborhood Method' classifies crimes that have a high propensity to be in neighborhoods that also receive a higher fraction of gang-related flags at the time of arrest. 
Table A2: Formal Employment By Gender

\begin{tabular}{lllll}
\hline \hline Bandwidths: & 4 & 6 & 10 \\
\hline
\end{tabular}

Panel A: Men Formal Employment in 2009

\begin{tabular}{lccc} 
Enrolled in SR & $-0.0539^{* * *}$ & $-0.0411^{* * *}$ & $-0.0301^{* * *}$ \\
& $(0.0166)$ & $(0.0103)$ & $(0.00811)$ \\
Number of observations & 133,067 & 180,742 & 247,886 \\
\hline
\end{tabular}

Panel B: Women Formal Employment in 2009
Enrolled in SR
$\begin{array}{ccc}0.00560 & -0.0130^{*} & -0.0169^{*} \\ (0.00757) & (0.00786) & (0.00889)\end{array}$
Number of observations
$156,942 \quad 213,755 \quad 292,980$

Note: Standard errors in parentheses. ${ }^{* * *}$ significant at $1 \%{ }^{* *}$ significant at $5 \%{ }^{*}$ significant at $10 \%$. We use the Sisben survey of 2009 to construct formal employment. Tables report two-staged least squares (2SLS) coefficients where the first stage is SR enrollment on being below the Sisben cutoff. Regressions control linearly for the 2002 Sisben score, flexibly around the cutoff. We cluster standard errors by comuna. 
Table A3: Baseline (2002 Sisben Survey) balance tests

\begin{tabular}{|c|c|c|c|}
\hline & Bandwidths: & 6 & 10 \\
\hline First Principal Component & $\begin{array}{c}0.0184 \\
(0.0158)\end{array}$ & $\begin{array}{c}-0.0023 \\
(0.0191)\end{array}$ & $\begin{array}{c}0.0282 \\
(0.0234)\end{array}$ \\
\hline Years of Education & $\begin{array}{c}0.0183 \\
(0.0685)\end{array}$ & $\begin{array}{c}0.00248 \\
(0.0606)\end{array}$ & $\begin{array}{l}-0.0408 \\
(0.0453)\end{array}$ \\
\hline Age & $\begin{array}{c}0.0339 \\
(0.0469)\end{array}$ & $\begin{array}{c}0.0255 \\
(0.0300)\end{array}$ & $\begin{array}{c}0.0177 \\
(0.0239)\end{array}$ \\
\hline Age Specific Education Gap & $\begin{array}{c}0.00566 \\
(0.0613)\end{array}$ & $\begin{array}{c}0.0159 \\
(0.0602)\end{array}$ & $\begin{array}{c}0.0580 \\
(0.0435)\end{array}$ \\
\hline HH Head Years of Education & $\begin{array}{l}-0.0463 \\
(0.0652)\end{array}$ & $\begin{array}{l}-0.0832 \\
(0.0592)\end{array}$ & $\begin{array}{c}-0.105^{* *} \\
(0.0451)\end{array}$ \\
\hline Unemployed & $\begin{array}{c}0.0166^{*} \\
(0.00878)\end{array}$ & $\begin{array}{c}0.0113 \\
(0.00738)\end{array}$ & $\begin{array}{c}0.00971 \\
(0.00726)\end{array}$ \\
\hline Married & $\begin{array}{c}0.0161 \\
(0.0228)\end{array}$ & $\begin{array}{c}0.0275 \\
(0.0175)\end{array}$ & $\begin{array}{r}0.0307^{* * *} \\
(0.0106)\end{array}$ \\
\hline Employed & $\begin{array}{r}-0.00846 \\
(0.0129)\end{array}$ & $\begin{array}{l}-0.0115 \\
(0.0102)\end{array}$ & $\begin{array}{c}-0.0182^{* *} \\
(0.00760)\end{array}$ \\
\hline Attending School & $\begin{array}{r}-0.000226 \\
(0.00247)\end{array}$ & $\begin{array}{l}0.000756 \\
(0.00270)\end{array}$ & $\begin{array}{l}0.000217 \\
(0.00221)\end{array}$ \\
\hline Neighborhood Stratum 2 & $\begin{array}{c}-0.00551 \\
(0.0215)\end{array}$ & $\begin{array}{l}-0.0129 \\
(0.0144)\end{array}$ & $\begin{array}{c}0.00394 \\
(0.0110)\end{array}$ \\
\hline Neighborhood Stratum 1 & $\begin{array}{c}0.0199 \\
(0.0201)\end{array}$ & $\begin{array}{l}0.0236^{*} \\
(0.0126)\end{array}$ & $\begin{array}{c}0.00311 \\
(0.00955)\end{array}$ \\
\hline Own House & $\begin{array}{c}0.0249 \\
(0.0159)\end{array}$ & $\begin{array}{c}0.0218 \\
(0.0127)\end{array}$ & $\begin{array}{l}0.0192^{* *} \\
(0.00789)\end{array}$ \\
\hline Less than 6 years Olds & $\begin{array}{c}0.00783 \\
(0.0104)\end{array}$ & $\begin{array}{c}0.0131 \\
(0.0129)\end{array}$ & $\begin{array}{l}0.0201^{*} \\
(0.0113)\end{array}$ \\
\hline HH Head Age & $\begin{array}{r}-0.000226 \\
(0.00247)\end{array}$ & $\begin{array}{l}0.000756 \\
(0.00270)\end{array}$ & $\begin{array}{c}0.000217 \\
(0.00221)\end{array}$ \\
\hline Observations & 181,132 & 246,974 & 340,581 \\
\hline
\end{tabular}

Note: Standard errors in parentheses. ${ }^{* * *}$ significant at $1 \%{ }^{* *}$ significant at $5 \%{ }^{*}$ significant at $10 \%$. Tables report reduced form coefficients on being below the Sisben cutoff, where Sisben score is measured in 2002. Regressions control linearly for the Sisben score, flexibly around the cutoff. All variables are measured in 2002. We cluster standard errors by comuna. Neighborhood strata indicate the official socioeconomic strata of the neighborhood. First Principal Component takes the first principal component of all other variables. 
Table A4: Baseline (2002 Sisben Survey) balance tests, Male Youth.

\begin{tabular}{|c|c|c|c|}
\hline & Bandwidths: & 6 & 10 \\
\hline First Principal Component & $\begin{array}{c}0.0174 \\
(0.0603)\end{array}$ & $\begin{array}{r}-0.00246 \\
(0.0446)\end{array}$ & $\begin{array}{c}-0.0158 \\
(0.0300)\end{array}$ \\
\hline Years of Education & $\begin{array}{c}0.0411 \\
(0.0629)\end{array}$ & $\begin{array}{c}0.0275 \\
(0.0552)\end{array}$ & $\begin{array}{l}-0.0247 \\
(0.0401)\end{array}$ \\
\hline Age & $\begin{array}{c}0.0132 \\
(0.0129)\end{array}$ & $\begin{array}{c}0.00976 \\
(0.0113)\end{array}$ & $\begin{array}{c}0.00376 \\
(0.00913)\end{array}$ \\
\hline Age Specic Education Gap & $\begin{array}{l}-0.0321 \\
(0.0590)\end{array}$ & $\begin{array}{l}-0.0208 \\
(0.0600)\end{array}$ & $\begin{array}{c}0.0260 \\
(0.0415)\end{array}$ \\
\hline HH Head Years of Education & $\begin{array}{l}-0.0167 \\
(0.0647)\end{array}$ & $\begin{array}{l}-0.0560 \\
(0.0583)\end{array}$ & $\begin{array}{c}-0.0840^{*} \\
(0.0436)\end{array}$ \\
\hline Unemployed & $\begin{array}{l}0.0179^{* *} \\
(0.00846)\end{array}$ & $\begin{array}{c}0.0111 \\
(0.00697)\end{array}$ & $\begin{array}{c}0.00924 \\
(0.00737)\end{array}$ \\
\hline Married & $\begin{array}{c}0.0171 \\
(0.0227)\end{array}$ & $\begin{array}{c}0.0254 \\
(0.0175)\end{array}$ & $\begin{array}{c}0.0314^{* * *} \\
(0.0109)\end{array}$ \\
\hline Employed & $\begin{array}{c}-0.0204^{* *} \\
(0.00968)\end{array}$ & $\begin{array}{l}-0.0139 \\
(0.0106)\end{array}$ & $\begin{array}{c}-0.0123 \\
(0.00998)\end{array}$ \\
\hline Attending School & $\begin{array}{r}-0.000356 \\
(0.00241)\end{array}$ & $\begin{array}{c}0.000788 \\
(0.00271)\end{array}$ & $\begin{array}{r}0.000270 \\
(0.00224)\end{array}$ \\
\hline Neighborhood Stratum 2 & $\begin{array}{l}-0.00588 \\
(0.00932)\end{array}$ & $\begin{array}{l}-0.00299 \\
(0.00713)\end{array}$ & $\begin{array}{c}0.00571 \\
(0.00626)\end{array}$ \\
\hline Neighborhood Stratum 1 & $\begin{array}{c}-0.00118 \\
(0.0163)\end{array}$ & $\begin{array}{c}0.00362 \\
(0.00916)\end{array}$ & $\begin{array}{c}-0.00524 \\
(0.00796)\end{array}$ \\
\hline Own House & $\begin{array}{c}0.0116 \\
(0.0147)\end{array}$ & $\begin{array}{l}0.00752 \\
(0.0110)\end{array}$ & $\begin{array}{c}0.0114^{*} \\
(0.00646)\end{array}$ \\
\hline Less than 6 years Olds & $\begin{array}{l}0.00745 \\
(0.0103)\end{array}$ & $\begin{array}{c}0.0122 \\
(0.0126)\end{array}$ & $\begin{array}{c}0.0187 \\
(0.0112)\end{array}$ \\
\hline HH Head Age & $\begin{array}{l}0.341^{*} \\
(0.167)\end{array}$ & $\begin{array}{c}0.338 * * \\
(0.136)\end{array}$ & $\begin{array}{c}0.220^{* *} \\
(0.100)\end{array}$ \\
\hline Observations & 21,366 & 28,675 & 38,888 \\
\hline
\end{tabular}

Note: Standard errors in parentheses. ${ }^{* * *}$ significant at $1 \%$; ${ }^{* *}$ significant at $5 \%$; ${ }^{*}$ significant at $10 \%$. Tables report reduced form coefficients on being below the Sisben cutoff, where Sisben score is measured in 2002. Regressions control linearly for the Sisben score, flexibly around the cutoff. All variables are measured in 2002. We cluster standard errors by comuna. Neighborhood strata indicate the official socioeconomic strata of the neighborhood. First Principal Component takes the first principal component of all other variables. 
Table A5: Less Gang-related Crimes: Heterogeneity by Comuna

\begin{tabular}{|c|c|c|c|c|}
\hline & Bandwidths: & 4 & 6 & 10 \\
\hline \multicolumn{5}{|c|}{ Panel A: Less Gang-Related Violent Crimes } \\
\hline Enrolled in SR & & $\begin{array}{c}0.00886 \\
(0.0167)\end{array}$ & $\begin{array}{c}0.00333 \\
(0.0114)\end{array}$ & $\begin{array}{r}-0.00421 \\
(0.0123)\end{array}$ \\
\hline Enrolled* Gang Comuna & & $\begin{array}{l}0.00773 \\
(0.0240)\end{array}$ & $\begin{array}{l}0.00236 \\
(0.0150)\end{array}$ & $\begin{array}{c}0.0126 \\
(0.0144)\end{array}$ \\
\hline F stat & & 92.6 & 134.6 & 204.3 \\
\hline Number of observations & & 18,419 & 24,768 & 33,702 \\
\hline
\end{tabular}

Panel B: Less Gang-Related Property Crimes

\begin{tabular}{lccc} 
Enrolled in SR & -0.00571 & -0.00526 & -0.00503 \\
& $(0.0168)$ & $(0.0120)$ & $(0.00969)$ \\
Enrolled* Gang Comuna & -0.0176 & -0.0122 & -0.0100 \\
& $(0.0180)$ & $(0.0153)$ & $(0.0122)$ \\
F stat & & & \\
Number of observations & 100.2 & 161.8 & 241.4 \\
& 18,240 & 24,523 & 33,358 \\
\hline
\end{tabular}

Panel C: Less Gang-Related Drug Crimes

$\begin{array}{lccc}\text { Enrolled in SR } & -0.0379 & -0.0494 & -0.0292 \\ & (0.0299) & (0.0307) & (0.0222) \\ \text { Enrolled* Gang Comuna } & 0.0132 & 0.0155 & 0.00281 \\ & (0.0292) & (0.0211) & (0.0195) \\ & & & \\ \text { F stat } & 94.8 & 135.1 & 197.3 \\ \text { Number of observations } & 19,150 & 25,740 & 35,104\end{array}$

Note: Standard errors in parentheses. ${ }^{* * *}$ significant at $1 \% ;{ }^{* *}$ significant at $5 \% ;{ }^{*}$ significant at $10 \%$. Tables report two-staged least squares (2SLS) coefficients where the first stage is SR enrollment on being below the Sisben cutoff and an interaction between high-gang comunas and being below the cutoff. The Sisben score is measure in 2002, SR enrollment in 2005, and crime outcomes are measured between 2005 and 2013. Regressions include comuna fixed effects and an interaction between high-gang comunas and indicators for SR enrollment. Regressions control linearly for the Sisben score, flexibly around the cutoff. We consider only males between 21 to 26 years old in 2013. We cluster errors by comuna. The mean arrest rate across all five gang comunas are $18 \%$, which is also the mean arrest rate in non-gang comunas. 
Table A6: Neighborhood Classification Method

\begin{tabular}{lllll}
\hline \hline Bandwidths: & 4 & 6 & 10 \\
\hline
\end{tabular}

Panel A: Gang-Related Violent Crimes

$\begin{array}{llll}\text { Enrolled in SR } & 0.0171^{* *} & 0.0121^{*} & 0.00891^{* *} \\ & (0.00751) & (0.00684) & (0.00387)\end{array}$

$\begin{array}{llll}\text { Number of observations } & 17,995 & 24,198 & 32,931\end{array}$

Panel B: Gang-Related Property Crimes

\begin{tabular}{lccc} 
Enrolled in SR & $0.0335^{* *}$ & $0.0271^{* *}$ & $0.0192^{*}$ \\
& $(0.0131)$ & $(0.0122)$ & $(0.0107)$ \\
Number of observations & 18,426 & 24,740 & 33,625 \\
\hline
\end{tabular}

Panel C: Gang-Related Drug Crimes

$\begin{array}{llll}\text { Enrolled in SR } & 0.0284^{*} & 0.0108 & -0.00197 \\ (0.0163) & (0.0126) & (0.0115)\end{array}$

Number of observations $\quad 18,909 \quad 25,447 \quad 34,661$

Note: Standard errors in parentheses. ${ }^{* * *}$ significant at 1\%; ** significant at 5\%; ${ }^{*}$ significant at 10\%. Tables report two-staged least squares (2SLS) coefficients where the first stage is SR enrollment on being below the Sisben cutoff. The Sisben score is measured in 2002 and SR enrollment in 2005. Crime data are from 2005 to 2013. Results use the neighborhood classification method described in the text to classify crimes. Regressions control linearly for the Sisben score, flexibly around the cutoff. We consider only males between 21 to 26 years old in 2013 . 
Table A7: Semi-parametric RD with Bias Correction

\begin{tabular}{|c|c|c|c|c|}
\hline & Type of Crime & Violent & Property & Drug \\
\hline Enrolled in SR & & 0.0164 & 0.02794 & 0.00768 \\
\hline Standard error & & $(0.00972)$ & $(0.01636)$ & $(0.02069)$ \\
\hline Bias corrected p-value & & 0.077 & 0.052 & 0.57 \\
\hline Bandwidth & & 5.2 & 5.8 & 6.6 \\
\hline Bias correction bandwidth & & 9.9 & 8.9 & 9.6 \\
\hline Number of observations & & 24,206 & 26,511 & 29,102 \\
\hline
\end{tabular}

Note: Results using the Calonico et al. (2014a) CCT method for estimation, where the primary estimation uses a linear functional form and the bias correction uses a quadratic form. Tables report fuzzy RD two-staged least squares (2SLS) coefficients where the first stage is SR enrollment on being below the Sisben cutoff, where Sisben score is measured in 2002. Crime data is from 2005 to 2013. We consider only males between 21 to 26 years old in 2013. 
Figure A5: Robustness to Bandwidths (Gang-Related Crime)
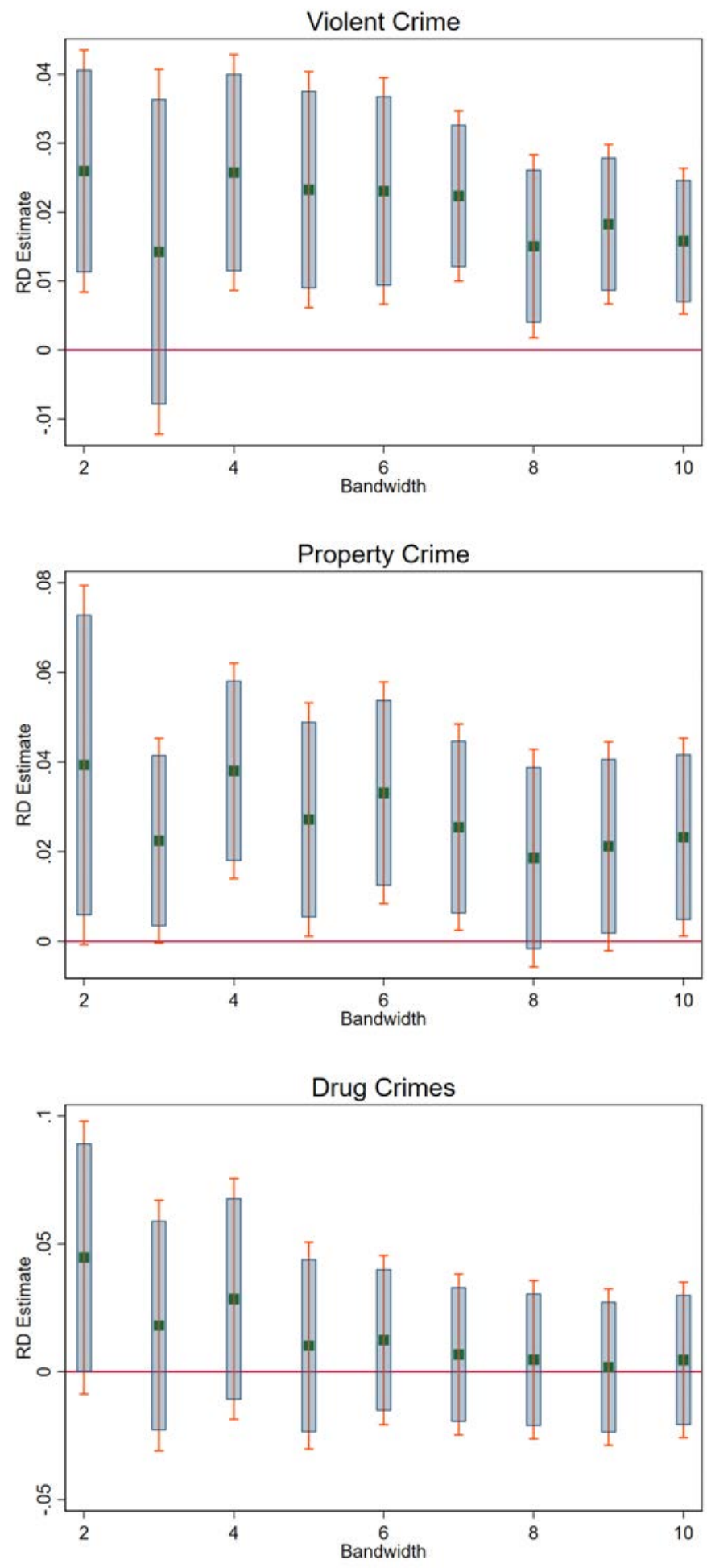

Note: Coefficients of RD 2SLS regressions where the first stage is SR Enrollment on being below the Sisben cutoff.

Sample of gang-related crimes only. Grey bars indicate $90 \%$ confidence intervals. Red lines indicate $95 \%$ confidence intervals. 
Table A9: Simultaneously both Non-formally Employed (in 2009) and Arrested

\begin{tabular}{lllll}
\hline \hline Bandwidths: & 4 & 6 & 10 \\
\hline
\end{tabular}

Panel A: Gang-Related Violent Crimes

$\begin{array}{lccc}\text { Enrolled in SR } & 0.0104 & 0.00997^{* *} & 0.00990^{* *} \\ & (0.00771) & (0.00405) & (0.00436)\end{array}$

$\begin{array}{llll}\text { Number of observations } & 12,015 & 16,023 & 21,733\end{array}$

Panel B: Gang-Related Property Crimes

$\begin{array}{lccc} & 0.0393^{* *} & 0.0331^{* * *} & 0.0183 \\ \text { Enrolled in SR } & (0.0184) & (0.0122) & (0.0128)\end{array}$

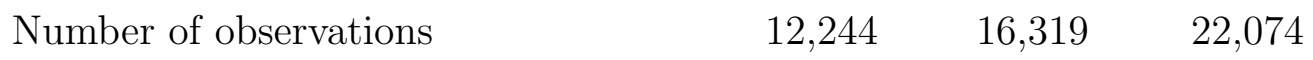

Panel C: Gang-Related Drug Crimes

$\begin{array}{lccc}\text { Enrolled in SR } & 0.0207 & 0.0299^{* * *} & 0.0291^{* *} \\ & (0.0177) & (0.00983) & (0.0126)\end{array}$

Number of observations $\quad 12,253 \quad 16,368 \quad 22,199$

Note: The outcome is arrests only for those not formally employed as measured in 2009. We exclude all arrests post 2009. Standard errors in parentheses. ${ }^{* * *}$ significant at $1 \%$; $* *$ significant at $5 \%$; ${ }^{*}$ significant at $10 \%$. Tables report two-staged least squares $(2 \mathrm{SLS})$ coefficients where the first stage is SR enrollment on being below the Sisben cutoff. The Sisben score is measured in 2002, and SR enrollment in 2005. Crime is measured between 2005 and 2009. Regressions control linearly for the Sisben score, flexibly around the cutoff. We consider only males between 21 to 26 years old in 2013. 